\title{
Cell-Cell Communication in the Tumor Microenvironment, Carcinogenesis, and Anticancer Treatment
}

\author{
Björn L.D.M. Brücher ${ }^{a, b, c}$ Ijaz S. Jamalla,b,d \\ Theodor-Billroth-Academy ${ }^{\circledR}$, Munich, Germany and Richmond, VA, USA; ' $I N C O R E$, International \\ Consortium of Research Excellence of the Theodor-Billroth-Academy ${ }^{\circledR}$, Germany and USA; 'Bon

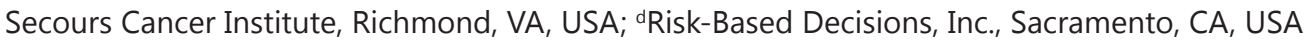

\section{Key Words}

Cell communication - Microenvironment - Carcinogenesis - Connexin • Gap junction • Pannexin • Integrin • Cadherin • Tight junction • E-cadherin • Cancer • Mutation • Inflammation - Wound healing • Fibrosis

\begin{abstract}
The delineation of key molecular pathways has enhanced our knowledge of the biology of tumor microenvironment, tumor dissemination, and carcinogenesis. The complexities of cell-cell communication and the possibilities for modulation provide new opportunities for treating cancers. Cells communicate by direct and indirect signaling. Direct cell-cell communication involves both, self-self-communication (intracrine and autocrine), and adjacent communication with nearby cells (juxtacrine), which themselves are regulated by distinct pathways. Indirect intercellular communication involves local communication over short distances (paracrine and synaptic signaling) or over large distances via hormones (endocrine). The essential components of cell-cell communication involve communication junctions (Connexins, Plasmodesmata, Ion Channels, Chemical Synapses, and Pannexins), occluding junctions (Tight Junctions), and anchoring junctions (Adherens, Desmosomes, Focal Adhesions, and Hemidesmosomes). The communication pathways pass through junctions at physical cell-cell attachments, and they go, as well, through the extracellular matrix (ECM) via the different transmembrane adhesion proteins (Cadherins and Integrins). We have here reviewed cell-cell communication involving (1) the components of junctions and their dynamic interplay with the other aspects of communication, including (2) the tumor microenvironment and carcinogenesis, (3) coupling and migration, (4) the underlying cell-cell and sub-cellular communication mechanisms (signaling) of anticancer treatments, and finally, (5) aspects of recent research on cell-cell communication.
\end{abstract}

Copyright (C) 2014 S. Karger AG, Basel

\section{Introduction}

Cell-cell communication is crucial for morphogenesis, cell differentiation, homeostasis, cell growth, and cell-cell interaction. McCrea described cell-cell communication as "the music

Björn LDM Brücher, MD, PhD,

FRCS (Engl), FACS, Professor of Surgery
Theodor-Billroth-Academy, Bon Secours Cancer Institute, Richmond, VA (USA)

Tel. +1804-393-4400, E-Mail b-bruecher @gmx.de

BB http://www.linkedin.com/in/bruecher

ISJ www.linkedin.com/pub/ijaz-jamall-ph-d-dabt/1b/69/b92 
that the nucleus hears" and, when dissonant, aberrant cell-cell communications may damage the health of the organism [1]. "Biological processes as well as cell-cell communication and signaling are themselves a multidimensional musical opera in different acts, which are played differently by different symphony orchestras rather than by a soloist. Even the composition of the music, which is needed before it can be played, is still not well understood." [2]. Achievements in anticancer therapy and as yet unmet opportunities, including the proposal for new anticancer strategies, have recently been reviewed [3]. To understand the music before it can be played, one should first look at the instruments involved. Some 80 years ago, a very insightful and courageous scientist for his era, K.H. Bauer, proposed a mutation theory to explain the origin of cancer [4]. His theory, although widely touted, remains unproven; and it is the source of a flawed paradigm. Mutations are most likely later events, or epiphenomena, in a multistep sequence of events through which the majority of cancers originate [2]. An understanding of cell-cell communication is important to understanding these sequential events that lead to a cancer.

Communication is the sharing of information by different signaling mechanisms: direct communication is self-self (intracrine or autocrine) or between nearby cells (juxtacrine), and indirect communication is local, exercised over a short distance (paracrine and synaptic signaling) or a longer distance (endocrine) (Table 1). Intercellular communications can be regulated by different versatile signaling pathways: intracrine communication is a mechanism that depends on the chemical structure of the signaling molecule and the specific target produced within the target cell, and autocrine communication targets the cell itself. For example, immune cells secrete signals extracellularly, and target cells are able to respond appropriately through specific receptor binding and signal transduction pathways. Different types of junctions, which connect cells to their microenvironment, are part of a communication network essential for signaling. The loss of cell-cell adhesion can be associated with a subsequent reduction of gap junctions or with local changes in the environment and these changes can then activate ion-related receptors in neighboring cells [5]. Such events demonstrate that different stimuli can have vastly different effects. However, it is daunting to apply the knowledge of communication between cells and their surrounding areas to the specific situation of tumor microenvironment and cancer cell development, as well as to later events of invasion, migration, and dissemination through tissues or organs and, finally, to its application in anticancer therapy.

In this paper, we review cell-cell communication involving (1) the components of junctions followed by their dynamic interplay with (2) the microenvironment and carcinogenesis, (3) coupling and migration, and (4) the underlying cell-cell and sub-cellular communication mechanisms (signaling) of anticancer treatments, as well as (5) new research aspects of cell-cell communication.

\section{(1) Components of Junctions for Cell-Cell Communication}

The junctions between cells (Table 2) include communication junctions, occluding junctions, and anchoring junctions. Different examples are illustrated in Figure 1. Communication junctions consist of Connexins (gap junctions in vertebrates), Plasmodesmata (gap junctions in plants), ion channels, chemical synapses and Pannexins. Neither Plasmodesmata nor chemical synapses will be discussed in this paper.

\section{Connexins (Gap Junctions)}

Connexins (gap junctions), comparable to Plasmodesmata in plants, are tube-forming protein complexes found between intracellular compartments in animals [6]. They provide a direct connection between the cytoplasm of one cell and the cytoplasm of an adjacent cell, allowing a flow of molecules along concentration gradients between connected cells when open, but blocking the flow without delay when closed [7]. More than 60 years ago, Weidmann discovered Connexins in nerve cells and Furshpan \& Potter found them in the myocardium $[8,9$, reviewed in 10$]$. A few authors have suggested that cell differentiation 
Table 1. Different signaling mechanism between and among cells

\begin{tabular}{llll}
\hline Different signaling mechanism & Produced signals & Explanation (Picture) \\
\hline Direct & Self-self communication & Intracrine & Signals are produced by the target cell, are secreted and effect the cell itself \\
& & Autocrine & Signals are produced by the target cell, that stay within the target cell and effect the targt cell itself by receptors \\
& Adjacent communication & Juxtacrine & Signals target adjacent cells, which are connected by cell-cell junctions by communication or anchoring junctions. \\
Indirect & Local communication & Paracrine & A cell secrets a molecule that interacts with a target nearby (example: neurotransmitter or cytokines) \\
& & Synaptic signaling & A cell releases a neurotransmitter (chemical signaling) into a synapse between two cells that are close together \\
& Long distance & Endocrine & Specialized cells release a molecule (hormone) into via blood stream and the hormone moves to a distant target to elicit \\
communication & response
\end{tabular}

Table 2. Cell-Cell junctions for cell-cell communication

\begin{tabular}{|c|c|c|c|}
\hline \multicolumn{2}{|l|}{ Function } & Names & Explanation \\
\hline \multirow{5}{*}{\multicolumn{2}{|c|}{ Communication Junctions }} & Connexins & $\begin{array}{l}\text { Gap junctions (in vertebrates) permitting the passage of ions and small molecules from cytoplasma of a cell to the one of the } \\
\text { adjacent cell }\end{array}$ \\
\hline & & Plasmodesmata & Gap junctions in plants \\
\hline & & Ion chanels & High rate of ions pass by electrochemical gradient \\
\hline & & Chemical synapses & Functional connections between neurons \\
\hline & & Pannexins & Transmembrane channels that connect the intracellular and extracellular space allowing the passage of ions and small molecules. \\
\hline \multicolumn{2}{|c|}{ Occluding Junctions } & Tight junctions & $\begin{array}{l}\text { Selective permeability: separating fluids, but enables molecules to pass. Adjacent cells form a sheet when connected by tight } \\
\text { junctions; molecules flow through the cells, but not between them and e.g. the barrier keeps the content of the gut within the lumen. }\end{array}$ \\
\hline \multirow[t]{6}{*}{$\begin{array}{l}\text { Anchoring } \\
\text { junctions }\end{array}$} & \multirow[t]{3}{*}{$\begin{array}{l}\text { Cadherin } \\
\text { related }\end{array}$} & $\begin{array}{l}\text { Adherens } \\
\text { (in epithelia: zonula } \\
\text { adherens) }\end{array}$ & $\begin{array}{l}\text { Actin is attached through a set of intracellular anchor proteins, including catenins, vinculin, and } \alpha \text {-actinin. The actin bundles are thus } \\
\text { linked, via the cadherins and anchor proteins, into an extensive transcellular network. }\end{array}$ \\
\hline & & Desmosomes & $\begin{array}{l}\text { Intracellular cadherin domain (of desmoglein and desmocollin) bind with intracellular anchor proteins (plakoglobin and } \\
\text { desmoplakin) to intermediate filaments }\end{array}$ \\
\hline & & & Extracellular cadherin domain holds the adjacent plasma membrane together \\
\hline & \multirow[t]{3}{*}{$\begin{array}{l}\text { Integrin } \\
\text { related }\end{array}$} & Focal Adhesions & $\begin{array}{l}\text { Intracellular integrin domain bind via intracellular anchor proteins (talin, } \alpha \text {-actinin, filamin, and vinculin) to actin filaments } \\
\text { Extracellular integrin domain bind to a protein component of the ECM }\end{array}$ \\
\hline & & Hemidesmosomes & Intracellular integrin domain bind via anchor protein (plectin) to keratin intermediate filaments \\
\hline & & $\begin{array}{l}\text { (connect to the the basal } \\
\text { lamina) }\end{array}$ & Extracellular integrin domain bind to laminin in the basal lamina \\
\hline
\end{tabular}

involves a complex set of events that are orchestrated by neighboring cells [11-13]. We contend that the microenvironment itself is part of the orchestra. Connexins mediate cell-cell communication during embryogenesis and tissue regeneration [14]. The molecules that pass through the junctions are typically small RNAs. From investigations in animal models, small RNAs are believed to be an important regulatory factor in determining the fate of a cell [15]. The protein family of Connexins (gap-junction proteins) was isolated and purified two decades ago from rat liver and insect cells [16]. These molecules within cell membranes have been investigated extensively with microscopy techniques $[17,18]$ and have been found to play an important role in cell-cell communication [19].
Fig. 1. Schematic drawing of junctions between epithelial cells.

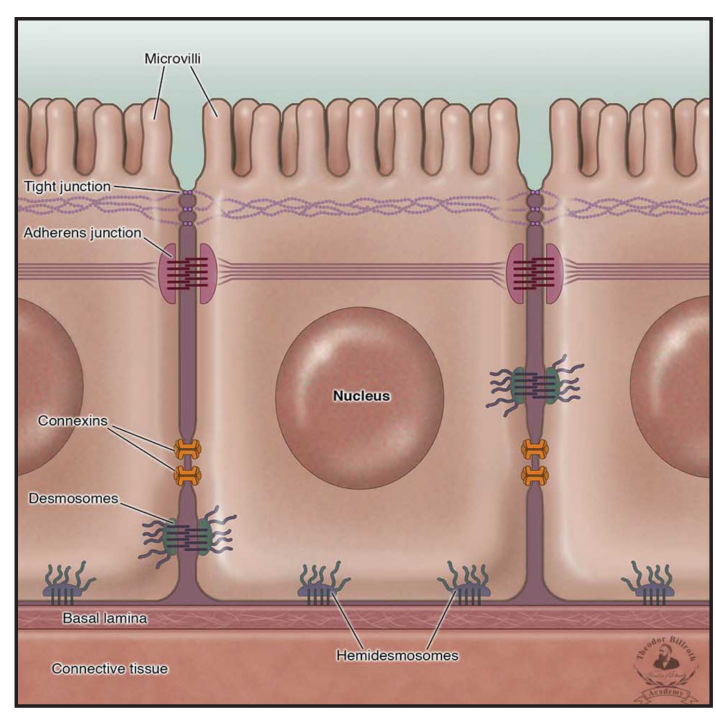

A variety of techniques, including analysis by electron crystallography and nuclear magnetic resonance (NMR) to determine the structure with its protein fragments, have been used on Connexins $[20,21]$. This body of research has shown that Connexins build channels through which small molecules of about $1 \mathrm{kD}$ can pass, enabling single cell communication as well as coordinating communications across tissues and organs [22-24]. Importantly, gap junctions play a pivotal role in contact inhibition. When normal cells are cultured in a petri dish, they form a single cell monolayer, before halting their growth, while cancer cells in such in vitro cultures pile up [25, 26]. Most fibroblasts have Connexins to communicate with neighboring cells [27]. By comparison, bone marrow adipocytes lack Connexins [28], but pre-adipocytes need Connexins for the differentiation process [29]. Additionally, the gap junctions in cardiac tissue allow direct intercellular exchange of the electrical impulses nec- 
essary for synchronous myocyte contractions and for the rhythmic contraction of the heart as an organ [30].

Connexins consist of paired hemichannels (Hcs, CxHcs): six protein subunits, when assembled, form a pore and a channel, which are projected into the cytoplasm and become a connexon [31]. A balanced internalization and degradation of the dodecameric Cx channel unit is responsible for the size of the gap junction [32, 33]. Hcs are recruited by the surrounding plasma membrane and enabled to dock with neighboring cells by directly attaching to the rims of pre-existing gap junctions [34]. Two Connexins from neighboring cells can form one complete intercellular gap junction channel, thereby establishing communication between two adjoining cells [35-37]. The composition of these channels changes during cell development, and the permeability of the channels may adapt to accommodate various molecules under different cellular microenvironments [13]. Connexins have remarkably rapid turnover rates for membrane proteins [10]. For example, the in vivo half-life of Connexin 32 (Cx32) in gap junctional plaques from rodent hepatocytes is less than 5 hours $[10,38]$, and the turnover of Connexin $43(\mathrm{Cx} 43)$ in tissue culture cells is even less $[10,39,40]$. These differences in half-life would suggest that cell culture studies of $\mathrm{Cx} 43$ would yield results in vitro different from those in vivo. Moreover, differences between the human and rat liver models have been reported, in which the former does not express the gene for Connexin and the latter does [41]. These discrepancies make comparisons among different studies and species-and even in vivo versus in vitro results-difficult to extrapolate to normal humans and much more so to diseased humans.

Before the molecular structure of cell walls began to be deciphered, connections between cells were believed to be limited to a physical contact that served only to tie one cell to another. Decades of research have led to the current understanding that they are also communication points. For example, Integrins allow bi-directional information flow both into and out of the cell, and they interact with different, known pathways. It is difficult to visualize the degree of fine tuning necessary for the communication mechanisms to function, just for the cell cycle. For example:

- Interphase G1 It includes cell growth, preparation for chromosomal replication, duplication of cellular components, and passing the G1 checkpoint (restriction point), where the cell either commits to division or exits.

- Interphase S-phase DNA replication and duplication of the centrosome are the key actions.

- Interphase G2-phase Cell growth occurs in this phase, and the system passes another checkpoint (restriction point), where the cell enters the M-phase.

- M-phase Cell division [mitosis or meiosis] takes place in phases: prophase, metaphase, anaphase, and telophase. The $\mathrm{M}$ phase is influenced by growth rate, cellular mass, time (more rapid growth during embryogenesis) and the completion of DNA replication.

\section{Ion Channels (the Sub-Cellular Level)}

Pore-formed ion channels, both anion and cation, are composed of channel,-or tunnelproteins, through which single proteins or protein complexes penetrate a cell membrane and catalyze the passage of specific ions through the membrane [42]. Ion channels serve as the sentinels of cell membranes: the ion balance across the cell membranes is maintained by the ion channels, which provide an energy-free ion transport route regulated by a concentration gradient. The ion transport velocity is often as great as $10^{6}$ ions per second; it is regulated by a combination of electrostatic (membrane potential) and osmotic (ion concentration) forces [43]. Ion channels are structured into ligand-gated (either extracellular or intracellular), voltage-gated, or mechanically gated channels; they control the flow of ions by size or by charge. The factors that determine whether a ligand-gated channel is open or closed depend on the concentration of the ligand and the activation/inactivation kinetics of the channel. Voltage-gated channels consist of four subunits, each with 6 transmembrane domains, or helices. The earliest research on ion channels, that of Sir Alan Hodgkin and Sir Andrew 
Huxley in electrophysiology, specifically on action potential theory, dates to the 1930s [44]. The work, interrupted by World War II, was revived afterward $[45,46]$. Erwin Neher and Bert Sakmann, by introducing their patch-clamping technique in the late 1970s, allowed the observation of single-channel molecules [47]. Examples of ligand-gated channels are the acetylcholine-gated chloride and glutamate-gated chloride channels. Important advances in the understanding of voltage-gated $\mathrm{K}^{+}$channels have come from physiological studies that used patch clamping, mutational studies of the Drosophila voltage-gated $\mathrm{K}^{+}$channel protein (a product of the Shaker gene), crystallographic analysis of the structure of the $\mathrm{K}^{+}$channels, and molecular modeling of permeation dynamics.

Lang et al. recently reported on the physiological elimination of infected or defective erythrocytes (eryptosis) involved in hemolysis. They found that it is triggered by oxidative stress and regulated by a complex signaling process consisting of $\mathrm{Ca}^{2+}$-permeable cation channels, ceramide, caspases, Janus-activated kinase 3 (JAK-3), adenosine monophosphate (AMP)-activated kinase, cyclic guanosine monophosphate (cGMP)-dependent protein kinase, casein kinase $1 \alpha$, P38 mitogen-activated protein kinase (p38, p38 MAP kinase, MAPK), and cyclin-dependent kinase inhibitor 1 (p21) activated kinase 2 (PAK2) [48]. We know the following ion channels so far: cation channels, through which $\mathrm{K}^{+}, \mathrm{Na}^{+}$, and $\mathrm{Ca}^{2+}$ can pass, and anion channels, for $\mathrm{Cl}^{-}, \mathrm{NO}_{3}^{-}$, and $\mathrm{C}_{3} \mathrm{H}_{2} \mathrm{O}_{4}^{-2}$, but we can imagine that others exist. One clue lies in the fact that red blood cells have nine relay switches in their "phone line" to eliminate defective erythrocytes. Since we know that ion channels are regulated by the environment and related signals, we can guess that many more factors, even, would be involved in nucleated cells.

\section{Pannexins}

Pannexins, which belong to a single protein superfamily [49], are transmembrane channels that connect the intracellular with the extracellular space. Small molecules such as ions and adenosine triphosphate (ATP) can migrate between the two spaces. The entire family of human Pannexins (also termed hemichannels) consists of three members: Pannexin 1, Pannexin 2, and Pannexin 3. The first, pannexin 1 (PANX1) is expressed ubiquitously, e.g., in brain, skeletal and heart muscle, testis, and ovary. Pannexin 2 (PANX2) is expressed predominantly in the central nervous system, and pannexin 3 (PANX3), in several embryonic tissues as well as adult bone, skin, and cartilage [50]. The Pannexins consist of four transmembrane segments, two of which are extracellular loops and two are cytoplasmic loops: one of these has an amino terminus and one, a carboxyl [50]. The structure of Pannexins, which have four conserved loop cysteines, is different from that of the Connexins, which have six. Pannexins differ also in the type of connection they have between cells and structures. Connexins are intercellular channels that span two plasma membranes, while Pannexins, constitute the membrane channels that provide, when open, a "phone line" between the intracellular cytosol and the extracellular space [50]. The term "Pannexon" describes the Pannexin oligomers (a hexamer in the case of PANX1 and an octamer for PANX2) [51, 52]. There is evidence that Pannexins function in single membrane environments: erythrocytes, which spend their entire life cycle as single cells, form membrane channels from Pannexins; they do not interact via gap junctions [50]. Sosinsky proposed that Pannexins are single membrane channels observed especially in blood cells, which exist and function as single cells and which express PANX1 [50]. They include macrophages [53], T-cells [54], and erythrocytes [55]. Universally, Connexins and Innexins promote intercellular interactions between the cells of solid tissues and circulating elements of the blood; they are expressed as half of a gap junction channel completed through a complementary interaction with another molecule $[9,56]$.

\section{Tight Junctions}

Tight junctions anchor neighboring cells together and also function between epithelial cells as a barrier to the diffusion of cells and proteins; they function not just as rigid, sealed cellular structures, as first thought. Models of tight junctions, which were first proposed in 1963, were expanded in 1970 [57, 58]. Tight junctions are known to regulate the passage 
of ions, water, and other molecules through a para-cellular pathway; they are impermeable to most macromolecules, but especially permeable to inorganic ions and more than 40 different proteins that have been discovered at tight junctions of epithelial, endothelial, and neuronal cells and major components of tight junctions are occludin, claudin, and junctional adhesion molecules (JAM) [59]. These observations reveal that tight junctions are highly specialized dynamic structures responsible for distinct permeabilities. Tight junctions are regulated by phosphorylation [60]. Since 1986, when the tight junction protein (ZO1) was first described by Stevenson, a number of different membrane domains have been discovered [61 and reviewed in 60]. Since then, tight junctions have been recognized to affect epithelial and endothelial function via crosstalk [62].

\section{Anchoring Junctions}

Anchoring junctions attach cells to neighboring cells within the ECM with transmembrane adhesion proteins-Cadherins or Integrins-in an interplay between a membrane protein and an ECM glycoprotein. Adherens (adherens junctions), Hemidesmosomes, and Desmosome junctions comprise trans-membrane proteins that have a cytoskeletal anchor and function by a membrane receptor ligand-mediated intercellular signaling that can operate through different trans-membrane pathways. These latter are involved in cell-cell, ECM, and basal membrane adhesion processes. Harmon and Green reviewed the early detection of Desmosomes, harking back to the observations made by Giulio Bizzozero in 1864 and to Schaffer's proposal, in 1920, of the name Desmosomes [6365]. Subsequently, these structures were shown to have an impact on morphological and functional differentiation [reviewed in 66] and to play an important role in the dissemination of cancer cells, as well as in epithelial-mesenchymal transition (EMT) [67, 68]. A decade ago, intercellular junctions and connections to the cytoskeleton and ECM were proposed to include signaling capabilities [69].

\section{Cadherin Anchoring Junctions}

Cadherins are anchor junction single-pass transmembrane glycoproteins; they can be either aAdherens or Desmosomes, which create the connection to actin filaments. The modulation of Cadherin extracellular binding triggers signals through the Desmosomes to the interior of the cell [70]. The activation of $\beta$-catenin stimulates cell proliferation by promoting pro-tumorigenic factors such as myc; both, this activation and the loss of E-Cadherin expression are observed in cancer [71].

\section{Adherens}

Adherens include proteins-Cadherins, $\alpha$-catenin, $\gamma$-catenin, or p120 catenin (p120)that are cell junctions linked to the actin cytoskeleton and to microtubules, thereby anchoring the cells through their actin filaments [72-74]. When Cadherins function as the transmembrane link, they connect cells; when Integrins do so, the connection is to the ECM. The morphological picture can be visualized as streaks or spot bands which are referred to as adhesion plaques.

\section{Desmosomes}

Desmosomes (maculae adherentes) contain dynamic transmembrane adhesion proteins such as desmoglein and desmocollin, which are members of the Cadherin family and which bridge intercellular adhesion of epithelial cells [75]. Their intercellular signaling pathways include the beta-catenin signaling pathway (Wnt), the p120 superfamily, the plakophilin superfamily, receptor tyrosine kinases/growth factor receptors, nectin-based signaling, small guanosine triphosphateses (GTPases), phosphoinositide-3 kinase (PI3 kinase), and protein kinase B (AKT or PKB). Six tight junction-associated transmembrane proteins have been identified: occludin, claudin, tricellulin, JAM, mammalian Crumbs3 (CRB3), and blood vessel/epicardial substance (Bves) [1, 76], as well as other different types of molecules that penetrate the cell. These can involve novel peptide signals, transcription factors that serve as intercellular signaling molecules, small RNA-mediated intercellular signaling molecules, and micro RNAs (miRNAs) that also function as intercellular signaling molecules [77]. 


\section{Integrin Anchoring Junctions}

Focal adhesions and hemidesmosomes. The Integrins function as Focal Adhesions or Hemidesmosomes, and they bind cells to the ECM with intermediate filaments. They are a family of transmembrane receptor proteins that integrate the cell with the extra- and intra-cellular framework [78], and they are not found in plants, fungi, or prokaryotes [79]. The cells communicate via signals that are transmitted along cell membranes by proteins. The signals are passed on to the target cell and/or the ECM via interactions with receptor molecules that, in turn, are integrated within the plasma membrane of the target cell. The history of the discovery of the system was recently reviewed [80]. Originally, mammals were thought to have $18 \alpha$ and $8 \beta$ subunits, each with a small cytoplasmic domain, and with the variants formed by splicing $[81,82]$. Now, Integrin ligands are believed to be of benefit for distinct drug-delivery systems [83]. In mice, knocking out the different Integrinencoding genes reveals distinct phenotypes, each with its identifying characteristic. Some of the defects found in the knockout phenotypes include blocked pre-implantation development, major developmental defects, perinatal lethality, and defective leukocyte function. Other defects were seen in placenta and lymphatic duct development, heart and kidney development, platelet aggregation, hemostasis, bone remodeling, phagocytosis, apoptosis, and angiogenesis as well as in inflammation of skin and airways and impaired lung fibrosis [Table 1 in 79]. These findings suggest that Integrins have not only a primary role in structural stabilization but also an impact on the embryological development of different tissues. Furthermore, Integrins influence and trigger signal transduction and, as evidence of their complexity, they can even be switched to an "on" or "off" position [79]. Integrins are bi-directionally connected to the surrounding ECM and to the information within the cell. They connect both the extracellular space, as integrins bind to the arginine-glycineaspartate (RGD) sequence with adhesive molecules (fibronectin, vitronectin, laminin), and the intracellular space, as they bind to the cytoskeletal proteins talin and $\alpha$-actinin, and they anchor the microfilaments.

Integrins interact with growth factors and ion channels [84]. For example, fibronectin is the major receptor for Integrin $\alpha 5 \beta 1$, and its binding results in an increase in the uptake of 2-deoxyglucose (2-DG), as well as glucose transporter 1 expression. This interaction was shown to occur through its binding with vascular endothelial growth factor receptor (VEGFR) 2 , and it led to successive activations of rat sarcoma protein (Ras) and phosphoinositide3-kinase/protein kinase B (PI3K/Akt). Fibronectin also increases the formation of a $\beta 1 /$ calcium channel protein complex and enhances calcium influx. Suh's experiments [84] revealed that the fibronectin formation increases both the cyclin D1 and the E expression; and it stimulates many pathways, including Ras, PI3K, phosphoinositide-3-kinase regulatory subunit 1 (alpha) (p85 $\alpha$ ), Akt, protein-kinase C (PKC), peroxisome proliferator-activated receptor-gamma (PPAR $\gamma$ ), and Ras homolog gene (Rho)-related GTP binding protein (RhoQ, TC10). It increases the F-actin/G-actin ratio, leading to an increase in cell proliferation and glucose transporter 1 (GLUT-1) synthesis through growth factors and their pathways (VEGFR2/Ras/PI3K/Akt) and through ion channels (calcium channel/ $\mathrm{Ca}^{2+} / \mathrm{PKC}$ ). In comparison, laminin, collagen I, and collagen IV activate Ras, PI3K, p85 $\alpha$, Akt, PKC, PPAR $\gamma$, and TC10, but not fibrinogen. Taken together, these findings imply that the ECM is not just a structural scaffolding element but is also actively involved in the exchange of information among the cells and molecules in its environment [84].

Hemidesmosomes form an adhesive attachment between the basal cell surface and the basement membrane, and they lend cohesiveness to the ECM [85], providing a stable connection to keratinocytes, especially within the epidermal basement membrane $[85,86]$. In comparison to Desmosomes, which consist of transmembrane molecules of the Cadherin family, Hemidesmosomes - half a Desmosome-are mediated by Integrins, but they do not serve just as cell stromal coherence elements [87]. Integrin $\alpha 6 \beta 4$ helps in the organization of the cytoskeleton $[88,89]$ by binding to laminin-332 [90]. Hemidesmosomes also build the Hemidesmosomes-enriched protein complexes (HPC). These dynamic structures stabilize connections [90]. Additionally, Hemidesmosomes serve via $\alpha 6 \beta 4$ Integrin as signaling devices 
by participating in signal transduction from the ECM to the interior of the cell, with effects on cell proliferation and differentiation [85]. Hypoxic stress decreases Hemidesmosome density along the basement membrane $[91,92]$. Knock-out mouse models for the Integrin subunits $\alpha 6 \beta 4$ reveal epithelial detachment, as well as an absence of Hemidesmosomes [93].

Wound healing is a complex process that involves signaling cascades, control of apoptosis, cell migration, differentiation, and re-creation of tissue integrity. Reactive oxygen species (ROS) are produced intracellularly, in association with lipid peroxides, oxidases, and such redox-sensitive proteins as low molecular weight protein tyrosine phosphatase (LMW-PTP). LMW-PTP is an enzyme that inhibits Integrin signaling and causes the dephosphorylation of focal adhesion kinase (FAK, protein tyrosine kinase 2, PTK2), which, in turn, is required for wound healing [94]. It has been suggested that FAK can promote cancer metastasis by activating estrogen receptor 5 (ERK5) [95], and, more recently, the inhibition of FAK has been shown to suppress ovarian cancer cell migration, as well as tissue invasion [96]. ROS have also been shown important to oncogene-induced senescense, an initial barrier for cancer development. The ROS-protein kinase-C $\delta$ (PKC $\delta$ )-protein kinase D1 (PKD1) - axis is necessary for inducing a senescence-associated secretory phenotype, which is reportedly involved in cancer development, metastasis, and tissue repair [97]. One of the possible pathways by which cells communicate was seen when human melanoma cells (WM9), were exposed to simvastatin, which activated the p53/p21 pathway and induced a G1 arrest (senescent phenotype) and their intracellular ROS increased, as well [98]. On the other hand, an element upstream of p16(INK4a) seems to regulate the induction of senescence, as, in soft tissue and bone cancers, its downregulation is associated with tumor progression and reduced patient survival [99]. Connexin-43 (Cx43)-deficient hematopoietic stem cells (HSCs) exhibit an increased senescence that is dependent on their ability to transfer ROS to the hematopoietic microenvironment, and ROS accumulate in the HSCs. Thus, Cx43 has a protective effect on HSCs, which is exerted through their transfering the ROS to the hematopoietic microenvironment [100].

Ben-Jacob \& Levine reported their observations of self-engineering in bacteria, which could further our understanding of cell-cell communication [101]. They reported that bacteria "... can cooperatively make drastic alterations of their internal genomic state, effectively transforming themselves into practically different cells". Such a change or twist of the geometrical organization into different morphotypes requires intense communication the alteration of the internal genomic state that occurs when a change of chiral patterning is initiated, induced, and completed. The authors pointed out that, for this coordination to occur, "an ongoing chemical messaging system is needed" as well as a "hierarchical organization". Applying this same concept to human cells, and combining it with our knowledge of bacterial resistance to antibiotics, in which bacterial "... colonies are often more resistant than the individual cells" [101] might suggest that tumor cells in colonies have a higher rate of resistance than individual tumor cells and that tumor cells also might have a highly functional coordinated cell-cell communication strategy. Bacteria can monitor the presence of other surrounding bacteria, a process called "quorum sensing" [102]. The process is related to research first published in the 1950s [103, reviewed in 104]. The term "quorum sensing" was coined in 1994 by Fuqua et al. [105, reviewed in 104].

\section{(2) Cell-Cell Communication in Microenvironment and Carcinogenesis}

"Cancer is a complex and heterogeneous set of diseases with no simple definition" $[2,106]$. The orchestration of cell-cell communication during carcinogenesis is not well understood as it encompasses different feedback loops and both activating and inhibiting paths of different forms of communication, as well as a fine-tuning mechanism and disarrangement. "Even the composition of the music, which is needed before it can be played, is not well understood" [2]. 
Today, between 5 and $10 \%$ of cancer cases are thought to be triggered by mutation and up to $15 \%$ by inflammation; some $80 \%$ are still "sporadic" cancers, meaning their origin is unknown [2]. Increasingly, somatic mutations as drivers of carcinogenesis have been questioned $[2,107]$. Additionally, as was pointed out in a recent online discussion by the cell biologist Professor Vladimir Matveev, "Genes are of importance for metabolism and changes of those metabolic products would need a sufficient quantity of mutations. Even the clonal theory which is proposed to explain the rapid proliferation of cancer cells cannot account for the number of mutations observed in human cancers" [108]. Furthermore, genes are not just a blueprint for providing information; they are controlled by long, non-coding RNAmediated (lncRNA) repressor occlusions, by an active outside to inside pathway; by this cyclooxygenase-2-IncRNA, also known as PACER, was identified as a new potential target for COX-2-modulation in inflammation and cancer [109]. The nuclear membrane forms a barrier around the nucleus and its genetic information, but nature provides it with a discontinuous fence that allows a bi-directional intra-cellular communication with the cytoplasm. Some 60 years ago, Porter, using electron microscopy, demonstrated streets, or highways, that connect ground substances like hyaloplasm with the nucleus, by tubules [110,111]. Not only are cells connected to the surrounding content, but stroma also connects to the basal membrane [112], from which information can be transmitted and processed. Additionally, it has recently been shown that, during a retrovirus infection such as HIV, an enzyme related to activation-induced deaminase (AID), namely apolipoprotein B mRNA-editing enzyme catalytic polypeptide 3 (APOBEC3), can also mutate antibodies by a yet-unidentified mechanism [113]. It may be of further importance that DNA double-strand breaks (DSBs) can be repaired with inserts of 50- to 1,000-bp sequences-termed "templated-sequence insertions" (TSIs) - derived from distant regions of the genome. The finding indicates that the source of the repair template was primarily nuclear RNA [114].

It has recently been suggested that mutations are late events, or epiphenomena, in a multistep sequence of events that can describe the origin of the majority of cancers [2]. The postulated sequences, including the underlying cell-cell communication, consist of (1) a pathogenic stimulus followed by (2) chronic inflammation, (3) fibrosis accompanied by changes in the microenvironment, which lead to (4) a pre-cancerous niche and (5) the development of a chronic escape strategy which-if unresolved-induces (6) a transition from normal cell to cancer cell [2].

A pathogenic stimulus - acute or chronic-interacts first with the contact layer of a mammalian cell, the surface proteoglycan layer (glycocalyx) [2]. The glycocalyx encompasses five different classes of adhesion molecules (immunoglobulins, integrins, cadherins, selectins, and cell adhesion molecules) that directly connect it to the ECM [2]. Furthermore, the glycocalyx of the plasma membrane directly influences the ability of cells to form gap junction channels [115, reviewed in 116]. In this manner, the glycocalyx itself influences how information is filtered and forwarded. Endothelial cells and vascular smooth muscle cells can communicate with each other directly-electrically-through Connexins, to control vasomotor tone; Connexins work in concert in vascular structures, with no redundancy [117]. This finding suggests the importance of the communication between the glycocalyx and both the underlying cell structures and the ECM. Blocking the glycocalyx components heparin sulfate and hyaluron has recently been shown to decrease the invasiveness of cancer cells [118]. Together with the newly proposed paradigm for the origin of cancer, not only could this finding lead to a treatment for metastasized tumors, but the principle itself could serve as the basis for a strategy to prevent cancer.

Hunter first defined inflammation some 220 years ago as a non-specific response to all kinds of injury, and he considered it a disease [posthumously published, 119]. Over 40 years ago, Anderson suggested that inflammation and subsequent healing should be considered separate events [106]. However, inflammation and any subsequent event related to it overlap; they cannot be distinguished in clear-cut chronological terms. Inflammation is the basis for wound healing, and it reflects a complicated, multifactorial, and multidimensional process, 
in which acute and chronic inflammation are differentiated. Not only are chronic and acute inflammation different, as submitted decades ago [120], but, as recent evidence suggests, not all chronic inflammation is the same [121]. However, chronic inflammation often appears as subclinical inflammation; the microenvironment that surrounds inflammation is characterized by greater oxidative stress than normal. Monocytes, lymphocytes, plasma cells, fibroblasts, and mast cells (MCs) are primarily involved in inflammatory processes [2], and Connexins such as $\mathrm{Cx} 43$ and $\mathrm{Cx} 32$ are synthesized and integrated into the cell membranes of MCs [122], monocytes [123], and leukocytes [124], all of which use Connexins to communicate with their microenvironment. Signaling through the $\mathrm{C}-\mathrm{X}-\mathrm{C}$ chemokine receptor type 6 (CXCR6) regulates macrophage, T-cell infiltration, and bone marrow-derived fibroblast accumulation in Ang II-induced renal injury and fibrosis. When CXCR6-GFP knockout mice were treated with Ang II, they expressed fewer fibroblasts than normal mice, less ECM protein, fewer F4/80(+) macrophages, and fewer CD3(+) T cells and expressed fewer proinflammatory cytokines in the kidney [125].

Stromal cell cytokines, such as tumor necrosis factor alpha (TNF- $\alpha$ ), activate the nuclear factor kappa light-chain enhancer of activated B cells (NF- $\kappa B$ ) and thus regulate the immune response. ROS also activate NF- $\kappa \mathrm{B}$, increase tumor suppressor genes, and increase oncogenes [126], and they also induce C-X-C chemokine receptor type 4 (CXCR4) expression, independent of stromal cell-derived factor 1 (SDF-1; synonym CXCL12) [127]. Chronic inflammation leads to the activation of continuous transforming growth factor-beta (TGF- $\beta$ ), which, through TGF- $\beta$-activated kinase 1 (TAK1/MEK)-mediated Akt activation, results, in turn, in ongoing NF- $\kappa B$ activation [128]. The NF- $\kappa B$ induces an ongoing cell profileration. Cyclin-dependent kinase 2 (cdc2-kinasis) catalyzes the phosphorylation of smad3, leading to a disruption of the complete TGF- $\beta$ cascade and thus initiating the cell-cycle for the transition G1-/S-phasis [129]. TGF-ß1-induced apoptosis occurs with the indirect activation of MAP kinases [130133], and it can also be induced by overexpression of smad7 $[131,134,135]$. The glutathioneS-transferases (GSTs), also relevant, inhibit members of the mitogen-activated protein kinase (MAP) family by building up protein-protein interactions and increasing GST activity, thus inhibiting the MAP kinases [136]. Data from head and neck cancers support this model [137]. Further evidence comes from research on prostate cancer that shows that a specific parasite-derived protein of Trichomonas vaginalis, macrophage migration inhibitory factor (TvMIF), can mimic the human homolog cytokine, human macrophage migration inhibitory factor (HuMIF), increasing inflammation and cell proliferation [138]. From such findings, one can infer that apoptosis-inducing chemotherapeutic agents, e.g., cisplatine, can be inhibited.

The progression from chronic inflammation to fibrosis as the sequences in a new paradigm for carcinogenesis has been reviewed in detail [2]. Knocking out $\alpha v$-integrin in liver fibroblasts of mice results in protection against liver fibrosis using different fibrosis models mice (liver: carbon tetrachloride (CCl4); lung: bleomycin; kidney: ureterobstruction) [139]. Smad3 is a crucial factor for the development of fibrosis, as the genetic deletion of smad3 (as in smad3 knockout mice) decreases both the activation of myofibroblasts and the generation of alpha smooth muscle actin ( $\alpha$-SMA) [140]. The intermediate protein smad transduces the information from TGF to the nucleus [141]. TGFß activation gives rise to smad3 phosphorylation [141] at the SSXS motif in the C-terminal tail and at three (S/T)-P sites in the smad3 link region: Ser(208), Ser(204), and Thr(179) [142]. The smad3 phosphorylation by TGF is ERK independent [142]. The TGFß-induced phorphorylation of smad3 regulates the coactivator p300/CREB-binding protein [141], and this crosstalk effects an inhibition of anti-proliferative activity. Furthermore, madecassoside (Mad), a triterpenoid saponin isolated from Centella asiatica, reduces the expression of $\alpha$-smooth muscle actin and TGF- $\beta 1$, and it also inhibits the phosphorylations of smad2 and smad3 in lung tissues, preventing thus the deposition of ECM, which ameliorates pulmonary fibrosis in a mouse model [143].

Recently the vitamin D receptor (VDR) and its ligands were reported to inhibit the TGF $\beta 1$ activation of perisinusoidal cells (Ito cells, hepatic stellate cells, or HSCs), which are located between sinusoids and hepatocytes in the space of Disse. Their activation caused a marked 
attenuation or reversal of liver fibrosis [144]. HSC display characteristics of fibroblasts and smooth muscle cells, producing interstitial and basement membrane collagen, as well as the intermediate filament protein desmin $[145,146]$. Fibroblasts generally produce type I collagen [147], but not desmin [148]. HSC store vitamin A and are thought to be primarily inactive, becoming active only after liver damage, when they play a major role in bringing about liver fibrosis by producing excess ECM [145]. HSC also function as antigen-presenting cells (APCs) by stimulating the proliferation of natural killer T-cells (NKT cells) [149]. NKT cells string together characteristics of innate and adaptive immunity [150, reviewed in 151]: they activate receptors and express inhibiting receptors that sense the presence of the MHC class I molecules expressed on all healthy cells [152, reviewed in 151]. Cx43 regulates NKT activation: knockdown reduced CD69 and CD25 expression and also the IFN- $\gamma$ secretion usually released by NKT induced through human dendritic cells and blocking the Cx43suppressed NKT-mediated tumor cell lysis [153]. The $\alpha v$-containing Integrins are known to be essential for fibrosis [154], a pharmacological blockade of the $\alpha \mathrm{v}$-subunit has been shown to attenuate liver and lung fibrosis in mice treated with a novel small molecule, (CWHM 12) [155]. A review of all the findings on the $\alpha$ and $\beta$ subunits together highlights the fact that antagonizing $\alpha v ß 3$ Integrin in athymic mice injected with the human breast cancer cell line MDA-MB-435 with a small molecule antagonist suppresses bone metastasis [156].

The subcellular crosslink of different pathways with its fibrocarcinogenic potency was investigated in cases of infection with chronic hepatitis B virus (HBV) and of hepatocellular carcinoma (HCC) [157]. Phosphorylated smad3C signaling shifted to fibrocarcinogenic psmad3L signaling, as livers progressed from chronic hepatitis B infection to HCC. After nucleoside analogue treatment of 27 patients with HBV-related chronic liver disease, serum alanine aminotransferase (ALT) and HBV-DNA levels decreased dramatically. The decrease in HBV-DNA restored $\mathrm{pSmad} 3 \mathrm{C}$ signaling in hepatocytes while eliminating the fibrocarcinogenic pSmad3L signaling. These findings raise the possibility of using oral nucleoside analogues both to suppress fibrosis and reduce the incidence of HCC by successfully reversing phosphorylated smad3 signaling and also to alleviate liver disease that has progressed to cirrhosis in chronic HBV patients [157]. As was recently shown in previously gut-sterilized mice on different dietary regimens, which were treated with microbiota translocation simulating microbial imbalance (dysbiosis), a subclinical inflammation brought about an increased bacterial translocation of the colon, which itself triggers a progression in nonalcoholic fatty liver disease (NAFLD) to non-alcoholic steatohepatitis (NASH) [158]. In another fibrosis mouse model, VEGF was shown to promote fibrogenesis as well as hepatic tissue repair and a resolution of fibrosis. The inhibition of VEGF by neutralizing antibodies (mcr84) abrogated (1) the chemokine (C-X-C motif) ligand 9 (CXCL9) on mRNA and protein levels and (2) the matrix metallopeptidase 13 (MMP13), both of which are necessary for triggering fibrosis [159]. These models could explain why obesity and dysbiosis are associated with cancer and carcinogenesis.

Integrins mediate the information exchanged between a cell and its surrounding components. These bidirectional communicating molecules allow both an inside-out and an outside-in flow of information, thus enabling the signal transduction of bidirectional information exchange between the ECM and the cell. With inside-out signaling, intracellular events modify the capacity of Integrins to bind to the ECM and, also, the interplay of cells and molecules within the ECM. Furthermore, an outside-in signal from the ECM to the intracellular space regulates gene expression $[160,161]$. In ovarian cancer, SDF-1 has recently been shown to upregulate the Integrin molecules $\beta 1$ and $\beta 3$ and to promote invasion by the SDF1-specific C-X-C chemokine receptor type 4 (CXCR4) axis [162]. In colorectal cancer, $\alpha \mathrm{v} 66$ Integrin was shown to effect the same kind of upregulation [163]. These findings may be of clinical relevance, as CXCR4, often expressed and detected in cancers, is found only at low or non-detectable levels in healthy tissues [164]. Therefore, the interaction between the ECM and integrins seems to play a role in metastasis. As the "... cytoskeleton of a typical epithelial cell and many cancer cells is not adapted to withstand stresses ..." [165], it may be that the continuous pathogenic stimulus manifested as chronic inflammation, and proposed also 
as two of the fundamental starting sequences of carcinogenesis [2], gives rise to a chronic outside-in signaling that involves the SDF-1/CXCR4 axis. For example, in breast cancer cells knocked out for SDF-1, exogenously applied SDF-1 prevented contact inhibition between breast cancer cells and bone marrow stroma, revealing that SDF-1 regulates interactions within the stroma of bone marrow [166]. SDF-1 in brain cells has a mitogenic effect [167] comparable to that of basic fibroblast growth factor (bFGF) in rat cortical cultures [168]. Most recently, quantitative phosphoproteomic analysis revealed several previously unidentified phosphoproteins and signaling pathways in breast cancer stem cells (CSCs) [169] that appear essential for triggering relapse and metastasis [170].

Data showing that inhibiting lysyl oxidase (LOX) prevents both fibrosis and metastatic colonization [171] demonstrates the assumption that fibrosis, with continuous remodeling of the microenvironment mediated by the copper $(\mathrm{Cu})$-dependent amine oxidase (LOX), creates a pre-cancerous niche (PCN) [2]. The subterranean blind mole rat (Spalax) is a cancerresistant species that tolerates hypoxia. During its long, 30-year life, it does not succumb to cancer [172]. In vitro experiments have revealed that fibroblasts from the Spalax actively suppress cancer cell growth. Other research, in the naked mole rat (Heterocephalus glaber), which has a similar lifespan and is also resistant to cancer, showed that its fibroblasts secrete a high-molecular-mass hyaluronan that accumulates in the tissues, with a consequent decrease in the activity of hyaluronan synthase 2 [173]. The two experiments provide evidence that fibrosis is necessary for carcinogenesis [2]. A crucial element seems to be the remodeling of the ECM into a pre-cancerous niche (PCN), as attempts to induce carcinogenesis chemically in Spalax result in lesions that heal, leaving no evidence of malignancy [172].

As cited above, the "... cytoskeleton of a typical epithelial cell and many cancer cells is not adapted to withstand stresses" [165]. We think it plausible that the ongoing chronic inflammation and remodeling of the ECM generate a pre-cancerous niche (PCN) which, if persistent, develops a chronic stress escape strategy (CSES) during carcinogenesis. The end result is a normal-cell to cancer-cell transition (NCCCT) [2]. The transition of one kind of cell to another is an event routine rather than rare [2]. Further evidence for cell transition comes from research on pancreatic cells that revealed that $\beta$ cells undergo both de-differentiation and re-differentiation, a particular that demonstrates the reversibiity of their phenotype [174].

Our paper reviews the multiple cell-cell communication pathways, such as ion channels, receptors, adhesion molecules, and the glycocalyx, that are expressed in the cell membrane. They may be viewed as a kind of adaptive response, and they can also be seen in their role in shear stress. Each of these pathways functions as a shear stress sensor, which engenders an actin-mediated mechanotransduction [175]. The ongoing information (in this case, the shear stress) is transduced to the cytoskeleton, which then alters the distribution of glycocalyx components. The events suggest a reorganization of the membrane microdomains, synonymous with an adaptive reaction, with resultant changes in the ECM.

\section{(3) Cell-Cell Communication, Coupling, and Migration}

Cell-cell communication is essential, both for normal and malignant cells, in determining whether they migrate and they remain in place. That evidence may account for the occasional clinical finding of metastasis without a diagnosable primary tumor. It has long been known that the ECM is essential for cellular differentiation [176]. The ECM directly influences the differentiation of many cell types, as well as stabilizing ligament fibroblasts [177]. Moreover, only about $50 \%$ of patients with disseminated tumor cells and circulating tumor cells (CTCs) develop clinically evident metastatic cancer; only $0.01 \%$ of those with disseminated cells and CTCs develop metastasis $[178,179]$. Something unique about the tumor microenvironment and the ECM must create conditions favorable for metastatic cancers to proliferate at certain locations but not at others. These observations bring us back to evolution because chemical communication and chemical signaling from one cell to another set up important effects 
[180]. Stoka stated that "The earliest phylogenetic example of intraspecific communication at cellular organization level is the aggregation process..." [180, 181]. Those autocrine-induced interactions have been described in detail in the protozoan Euplotes raikovi, with attention to the autocrine effects on cell division and the paracrine effects on mating behavior [180, 182].

The hypothesis that Connexins correlate negatively with tumor grade, and that they likely play a suppressor role in carcinogenesis, derives from observations of a reduced level of Connexin expression in cancer cells and the degree of cell coupling among them [183-187]. However, the gap junction network remains incompletely understood. As immunological knowledge improves and is applied to cancer therapy [188], the relevance of this network will be better contextualized. Connexins that have been proposed as regulators of hemostasis and thrombosis [189] and as regulators of immunocompetent cells, monocytes, and T-cells $[56,190]$ may finally feature more prominently than they do today.

Mesnil et al. have described the loss of proper coupling capacity in numerous cell types, independent of their origin in tissue or organ, and they differentiated among the degrees of loss, from a total absence of coupling to a slight alteration [191], and, in some cancers, these may correlate with tumor progression [192, 193] and prognosis [194]. The importance of proper coupling as a suppressor of tumor growth has been confirmed in experiments in several human and animal cell lines that forced the expression of the gene for Connexins $[195,196]$. Interestingly, the carboxyl end of the Connexin intracellular domain can directly affect the growth of cells [197]. Overexpression of Connexins in E9 mouse lung carcinoma cells and WB-aB1 neoplastic rat liver epithelial cells was elicited by forced expression of the gap junction proteins, Connexin43 ( $\mathrm{Cx} 43$ ) and Connexin32 (Cx32), to the level of their respective normal sister cell lines [198]. As a consequence, these cells had percentages of G1 cells comparable to normal non-tumorigenic cells; the growth control of the G(1) phase was restored by increasing Connexin expression with its intercellular communication [198].

Methylation, although frequently reported in promoter regions of inhibited genes in cancer, does not appear to be responsible for regulating the expression of Cx26 in the human esophageal cancer cell line [199]. However, in breast cancers, methylation of CpG islands appears to be important for the expression of connexon [200]. Sphingolipids have been tested in colon cancer cell lines with evidence that they suppress $\beta$-catenin and upregulate $\mathrm{Cx} 43$, both of which have been correlated to colon cancer [201]. In addition to their physical docking to neighboring cells, Connexins appear to modify the expression of other docking molecules, such as E-Cadherin, further inhibiting cell migration [202]. In transformed rat liver cells, $\mathrm{Cx} 43$ protein is located in the nucleus, a finding that leads to speculation that Connexins might be involved in signaling within the nucleus [191]. Arregui et al. recently reported that $\alpha$-actinin and the focal adhesion kinase $S r c$ - two substrates of the endoplasmic reticulum-bound protein tyrosine phosphatase (PTP1B) - mediate an interaction between Integrins and the cytoskeleton. They also found that promoting small signaling GTPaseprotein Rac1 activation and inhibition of RhoA (Ras homolog gene, family member A) affects both lamellar dynamics and directional cell migration [203].

\section{(4) Cell-Cell Communication and Anticancer Treatment}

\section{Radiotherapy}

For several decades after the discovery of X-rays, the deleterious and therapeutic effects of ionizing radiation were attributed primarily to direct damage to DNA. In the past 20 years, the fact that cells not directly irradiated also show long-term extranuclear effects that may contribute to a wide spectrum of radiation-induced effects, the "bystander effects" has become increasingly evident. Nagasawa and Little first reported these in 1992 [204]. Since the early demonstration that targeted cytoplasmic irradiation caused mutations in the nuclei [205], the questions these early observations have raised include the following: How do these effects occur? What is the nature of these extra-nuclear effects? What mechanisms might be involved? What are the clinical implications of bystander effects in multimodal 
cancer therapy? These questions and their answers-those that reflect influences on cellcell communications-are critically reviewed in this section.

Radiation-induced bystander effects are defined as those biological effects in cells that have not been directly traversed by ionizing radiation, but are in close proximity to cells that have been. In Chinese hamster ovary (CHO), cells irradiated by low doses of $\alpha$ particles, in which fewer than $1 \%$ of the cellular nuclei were actually hit by the ionizing radiation, an increase in sister chromatid exchanges was observed in 30\% of the cells [204]. Using microbeam technology, irradiating just one cell in a population of cells with a single ionizing particle has been shown to elicit bystander effects. Interestingly, bystander effects do not exhibit a dose-response relationship, at least not in vitro [206].

According to the available data, primarily from in vitro studies, the bystander effect falls into two categories: 1) in confluent cell cultures in which irradiated and non-irradiated cells make physical contact, gap junctions have been shown to mediate the bystander effect, and 2 ) in sparsely populated cell cultures in which the physical contact between cells is sparse, signal molecules from irradiated cells may be released into the culture medium to produce the bystander effect on non-irradiated cells [207]. The two categories are not mutually exclusive, and one or both may apply in a given situation. Both could be initiated by some common, as yet unidentified, process [208].

Azzam, et al. used inhibitors of gap junction-mediated intracellular communication and genetically engineered cells that lack gap junctions to show that the bystander effect involves gap junctions, specifically $\mathrm{Cx} 43$. To rule out effects due to changes in membrane fluidity or other cellular functions, they suppressed gap-junction activity with a dominant negative connexin construct [209]. Cells containing the dominant negative Cx43 vector showed little or no bystander mutagenesis. In contrast, cells containing the empty control vector did exhibit a bystander effect [210]. CHO cells that stably incorporate human chromosome 11 ( $A_{L}$ cells), that are dominant negative for $\mathrm{Cx} 43$, and that lack gap junctions, produced a complete attenuation of the bystander mutagenic response [209]. These findings show that gap-junction mediated intercellular communications play an important role in the bystander response that occurs near irradiated cells.

Seymour and Mothersill [211] first demonstrated a highly significant reduction in cloning efficiency in both non-irradiated normal as well as irradiated malignant epithelial cell lines. Their results suggested that irradiated cells secreted into the culture medium a cytotoxic factor capable of killing non-irradiated cells. In addition, transferring medium from low linear energy transfer (LET)-irradiated cultures to non-irradiated cultures led to increased levels of such various bystander effects as genomic instability, cell death [212], and even neoplastic transformation [213]. Studies with $\alpha$-particles, which travel only very short distances, demonstrated that the factor or factors released from irradiated cells could induce an increase in sister chromatid exchanges with no associated increase in mutagenesis, likely a consequence of an increase in cell death among the putatively mutated bystander cells $[214,215]$.

In an effort to identify the signaling molecules and pathways involved in the radiationinduced bystander effect, Zhou et al. deployed a signal-transduction pathway-specific SuperArray to compare differentially expressed genes among the non-irradiated NHLF and the bystander cells [216]. Among the 96 genes represented on the platform, the transcription level of COX-2 was found to be consistently upregulated by more than $300 \%$, while the RNA level of insulin growth factor binding protein-3 (IGFBP-3) was consistently inferior by more than 700\%, in multiple analyses of multiple bystander samples [216]. The expression of COX2 protein in non-irradiated bystander cells was further confirmed by Western blot with and without the COX-2 inhibitor, NS-398 [216]. These data indicate that the expression of COX-2 is connected to the bystander effect. If the COX-2 gene is causally linked to the bystander signaling pathways, it should be possible to modulate the bystander response using the 
specific inhibitor of COX-2 enzyme activity, NS-398. Although NS-398 treatment was able to reduce the hypoxanthine guanine phosphoryl transferase negative (HRPT-) mutant fraction in the directly irradiated cell population, the reduction of suppression was only $36 \%$ [217].

Insulin growth factor (IGF) and other cytokines activate the MAPK signaling cascade [216]. Activation of extracellular signal-related kinase (ERK) by phosphorylation is a key upstream event that precedes COX-2 expression [217]. Cell culture studies with and without PD98059, a specific MAPK-ERK inhibitor, showed suppression of the phosphorylated form of ERK in both, $\alpha$-particle irradiated and bystander cells. In fact, treatment of cells with a non-cytotoxic dose of PD98059 completely suppressed the bystander toxicity observed in NHLF cultures [217].

Ionizing radiation induces two oppositely directed information flows that regulate cell response: from the nucleus to the cytoplasm and from plasma membrane receptors via the cytoplasm to the nucleus. Widely recognized as effects of ionizing radiation are the double strand DNA breaks (DSB) in genomic DNA and, also, the DSB-induced signaling that activates Ataxia telangiectasia-mutated (ATM) kinase in the nucleus following the initiation of the downstream ATM-mediated signaling pathways [218-220]. ATM-mediated phosphorylation and stabilization of p53 is a critical event in directly irradiated cells, which influences the cell's decision for growth arrest or cell death via the mitochondrial apoptotic pathway [221]. A general role for Rad3-related (ATR) ATM in the regulation of the bystander effect was postulated and subsequently confirmed [222, 223]. Somewhat surprisingly, however, the ATM-p53 signaling axis was not directly involved in the initiation of the bystander response [224]. Furthermore, a bystander effect was observed in p53-null cells [225]. In contrast, the alternative ATM-mediated pathway of NF- $\kappa \beta$, initiated at the nucleus, efficiently upregulated the NF- $\kappa \beta$-dependent gene expression of numerous stress genes [217]. The NF- $\kappa \beta$-dependent gene expression of interleukin 1 beta (IL-1B), IL-3, IL-6, IL-8, TNF, and PTGS2/COX-2, in concert with other NF- $\kappa \beta$ target genes in irradiated human skin fibroblasts, brought about the production of cytokines and their receptors, as well as COX-2-dependent prostaglandin E2 (PGE2) with autocrine/paracrine functions [226]. These signaling molecules might further activate signaling pathways in non-irradiated cells using plasma membrane receptor initiated pathways through the cytoplasm into the nucleus.

The paracrine functions of the cytokines, which are generated by directly irradiated cells, have been shown to activate cytokine receptor-mediated pathways in bystander cells, which themselves initiate the expression of IL-6, IL-8, IL-33, and COX-2, followed by autocrine/ paracrine stimulation of the NF- $\kappa \beta$ and MAPK pathways, as well as the signal transducer and activator of transcription 3 (STAT-3) pathways [223, 227]. These actions create a positively regulated loop that is capable of maintaining a permanent cytokine overexpression. The most distinct feature of the bystander response is its rapid onset: in experimental conditions, even just $30 \mathrm{~min}$ after $\alpha$-irradiation, non-target fibroblasts induced or upregulated NF-к $\beta$ dependent expression, IL-6, IL-33, and, in addition, matrix metalloproteinases (MMPs) 1 and 3 , and chemokine ligands 2, 3 and 5, in a total of 407 genes [224]. Inhibition of TNF- $\alpha$ or IL33 transmitting functions with the corresponding monoclonal antibodies contained in the culture medium, decreased NF- $\kappa \beta$ activation in both directly irradiated and bystander cells, thus confirming the presence of the secondary autocrine/paracrine loop regulating NF- $\kappa \beta$ dependent gene expression in both irradiated and bystander cells $[223,228]$.

The primary goal of radiotherapy in cancer is to induce cancer cell death by apoptosis, necrosis, or mitotic failure, while keeping minimal the effects on non-targeted healthy cells in the tumor vicinity. The massive production and release of pro-inflammatory cytokines by directly irradiated cells can initiate a strong inflammatory response in the bystander cells, a response that itself can lead to different end points, including the creation of pathological conditions favorable for further cancer development. Indeed, a close connection between inflammation and cancer has been demonstrated $[2,229]$. The principal players in these events, NF- $\kappa \beta$, IL6, and STAT-3, are involved in the modulation of the bystander response. 
With anti-inflammatory agents such as humanized monoclonal antibodies against TNF $\alpha$ and IL6, the use of small molecule inhibitors of COX-2 or IGF-1R might be a means to increase the efficiency of radiotherapy by damping the inflammatory response of bystander cells [217].

The effects of radiotherapy on non-targeted bystander cells are mechanistically well understood, as summarized above for in vitro systems. However, many of these effects, or signaling pathways, as they apply to cancers in vivo, remains unexplored. Also unknown is the extent to which radiation-induced changes create the pre-condition of a new pre-cancerous niche that could foment a recurrence or the development of a new cancer. Understanding the role of ionizing radiation in cell-cell communication provides the foundation for designing experiments that, in the coming decade, would allow us to benefit, from the mechanistic level to the level of patient care [230].

\section{Chemotherapy}

The discovery of aminopterin and nitrogen mustard in the mid 20th century marked the beginning of the search for anticancer agents [231-234, reviewed in 235]. Cell-cell communication, which plays important roles in healing tissue and restoring cellular integrity, covers not just cellular membrane relay stations, but also ion channels. It is known, for example, that the way cisplatin affects ion channels leads to subsequent consequences related to ion imbalance. Mahmud showed that cisplatin did not itself induce hemolysis, but it increased cytosolic $\mathrm{Ca}^{2+}$ and thereby indirectly could induce eryptosis [236].

Decreased levels of Connexins are associated with reduced inflammation as well as scarring [237, reviewed in 238]. Macrophages, in response to the withdrawal of IL-3, secrete IL-1 $\beta$ during apoptosis, which, thanks to the activation of inflammasome, causes inflammation. That outcome signifies that inflammation is activated during phagocytosis by the dying cells and their products [239]; the same group showed that the NACHT, LRR, and PYD domains-containing protein 3 (NALP3) plays a crucial role within this process, since, in mice NALP3-deficient macrophages, IL-1 $\beta$ secretion decreases. The authors also showed that ATP-release through Pannexin-1 channels of dying autophagic cells, $\mathrm{P}(2) \mathrm{X}(7)$ purinergic receptor activation, and a functional $\mathrm{K}^{+}$-channel with potassium efflux are all necessary participants in activating inflammasome. Inflammasomes can be a double-edged sword in cancer [240].

The use of chemotherapy, though widespread, is limited clinically, as the therapeutic effect of most of the drugs in the oncological pharmacopeia is nonspecific; they harm normal as well as cancer cells. The importance of understanding the potential implications of cell-cell communication for chemotherapy becomes evident just by considering the fact that about $75 \%$ of the patients treated with platinum derivatives will suffer effects from their ototoxicity, effects that affect their quality of life [241]. Their pathogeneity is not well understood, nor are alternate options for treatment available. Korean researchers showed that the inhibition of $\mathrm{Cx} 43$ in auditory House Ear Institute-Organ of Corti 1 (HEI-OC1) cells by $\mathrm{Cx} 43$ siRNA or $18 \alpha-$ GA might prevent cisplatin-induced ototoxicity. Treated HEI-OC1 cells challenged with cisplatin showed greater viability than the untreated cells (control group). They demonstrated that highly activated extracellular signal-regulated kinase and protein kinase B are involved in the observed anti-Cx43 protection [242].

Isoosmotic cell shrinkage occurs in erythrocytes when chloride in the surrounding medium is replaced with gluconate. The consequent increased cytosolic $\mathrm{Ca}^{2+}$ concentration, combined with oxidative stress and energy depletion, can generate eryptosis (erythrocyte death) [243]. This process can be inhibited by resveratrol (3,5,4'-trihydroxy-trans-stilbene), a natural phenol produced by several plants, which use this phenol to protect themselves from bacteria and fungi. Reversatrol has been suspected to have anticancer effects, although its mechanism of action is not known [243]. It is now suggested that treatment with resveratrol increases $\mathrm{Cx} 43$ gap-junction communication, as a knockdown of $\mathrm{Cx} 43$ resulted in a reduction of cell death after treatment with both cisplatin and resveratrol. Additionally 
the MAPK signaling pathway was activated, and the use of MAPK inhibitors also decreased the expression of Cx43 protein [244].

$\mathrm{N}$-acetylcysteine (NAC)-induced Connexin43 preservation in rats with myocardial infarction was shown to be mediated by protein kinase A (PKA)- and cAMP (Epac)dependent pathways, both of which inactivate glycogen synthase kinase-3 $\beta$ [245]. The alpha-carboxy terminus $1(\alpha \mathrm{CT} 1$ ) peptide is a 25 amino acid peptide from the C-terminus of $\mathrm{Cx} 43$, modified to promote cellular uptake. Treatment with $\alpha \mathrm{CT} 1$ mimics $\mathrm{Cx} 43$, leads to a decrease in inflammasome, and is beneficial for wound healing [246]. It has been suggested that using replicating bacteria, such as salmonella, as oncolytic agents, in conjunction with chemotherapy, would improve the efficacy of the chemotherapy. An acccumulation of salmonella in tumors brought about in increase of $\mathrm{Cx} 43$, enhancing the chemosensitivity to cisplatin [247]. Wiita et al., within hours after chemotherapy to induce apoptosis, employed an enzyme-driven technology to search for potential markers for the response to treatment: in the plasma of these patients with hematologic malignancy, they found numerous protein fragments-peptide $\alpha$-amines-that could serve as post-treatment proteolysis biomarkers. [248]. The technology could be developed for future use in quickly assessing the response to treatment.

It is thought that the loss of Connexins, or their function, could play an important role in neoplastic transformation [249], and that re-establishing Connexins could delay tumor progression [250, 251]. Treatment of human pancreatic cancer with 4-phenylbutyrate (4$\mathrm{PB})$, both, in vitro and in vivo, revealed a significant increase of $\mathrm{Cx} 43$ and an accompanying growth of pancreatic tumor cells [252]. The newly synthesized Cx43 was not observed within the cell membrane, but rather, within the cytoplasm.

Because PANX1, together with the purinergic receptor P2X7, is involved in both the congenital immune response and the apoptotic or pyroptotic cell death process [253], this mechano-sensitive and ATP-permeable Pannexin channel in the cell membrane may have similar potential. Recent research has suggested that calcium channels are actively involved in autophagy as well as its regulation [254]. There is a growing body of evidence indicating that new research will provide the link between calcium-permeable channels and inflammation, fibrosis, carcinogenesis, and cancer progression. A Hungarian group showed that, in a cohort of neoadjuvant treated breast cancer patients, increased Cx46 expression, and decreased $\mathrm{Cx} 26$ expression, correlated with an improved prognosis. Their findings, which may improve the assessment of the histopathological response, demonstrate another option in the use of cell-cell communication to evaluate histopathological responses [255].

\section{Immunotherapy}

The immune system, extremely complex, protects the organism against diseases with biological structures and processes not yet completely understood. Cancer immunotherapy uses the immune system as an anticancer approach. The principle of the therapy depends on the fact that cancer cells incorporate proteins or carbohydrates on their surfaces, which generally can be detected by the immune system. Huge efforts are underway to discover drugs that provoke an immune reaction to such surface targets. Cancer immunotherapy can be classified into cytokine, antibody, and cell-based (vaccine) therapies.

Many cytokines, such as GM-CSF, IL-7, IL-12, IL-15, IL-18, and IL-21, have been under investigation in clinical trials to test cytokine-based cancer immunotherapy. They include interferon- $\alpha$ (IFN- $\alpha$ ) for such blood cancers as chronic myeloid leukemia, follicular lymphoma, hairy-cell leukemia, AIDS-triggered Kaposi's sarcoma, and malignant melanoma. They also include interleukin-2 (IL-2) for renal carcinoma and renal cell carcinoma [256]. One major challenge is the pleiotropism of the redundant cytokine signaling, together with the simultaneous activating and suppressing functions, which may explain both the low therapeutic response rates and the associated toxicities [256]. 
Connexins have been reported to protect the organism against the cytokine-mediated inflammatory reaction of vascular endothelial cells [257], and it is assumed that cytokine therapy may be combined with a Connexin activation therapy in the future. Since ion channels have been shown to be actively involved, the mechanisms in cell-cell communication and immunology seem even more complicated: heparin sulphate (HS), a proteoglycan of the ECM, induces the membrane potassium channel (MaxiK) in the production of inflammatory cytokines [258]. Further, Chang-Chien et al. have found Connexins important in recycling potassium ions in inner ear cells of the zebrafish. They also discovered which homolog of Connexin in mammalian cells is akin to that of the zebrafish [259].

Antibody-based cancer immunotherapy causes a drug to bind to a target on a cell surface structure, leading to a cytotoxic antigen-antibody reaction. Another form of immunotherapy activates the complement system, a lifelong, innate but unadaptable, immune system that the adaptive immune system can recruit, and which contributes thus to consequent chemotaxis, opsonization, cell lysis, or agglutination. By itself, the complement system is complex. It operates within very tight regulatory mechanisms, as its activation brings about severe cell and tissue damage. Another antibody immunotherapy approach is to block a ligand from its interaction with a receptor or from serving as a payload for more conventional anticancer treatments such as chemotherapy or radiation [260]. Examples for approved antibody immunotherapy are monoclonal antibodies that bind such proteins as the B-lymphocyte antigen CD20 (ibritumomab tiuxetan, ofatumumab, and rituximab); the cell membrane receptor CD30, or TNFRSF8, (brentuximab vedotin); the transmembrane receptor CD33, or Siglec-3, (gemtuzumab ozogamicin); CD52 (alemtuzumab); the cytotoxic T-lymphocyte antigen 4 CTLA-4 (ipilimumab); the epidermal growth factor receptor EGFR (cetuximab, panitumumab); vascular endothelial growth factor VEGF (bevacizumab); and HER2/neu receptor (trastuzumab). The cell-cell communication between many of the proteins on the level of the Connexins calls for future research, as our efforts are in their nascent stages now. Even so, investigations in neoadjuvant-treated breast cancer patients have shown pretherapy $\mathrm{Cx} 43$ to be associated with hormone receptor status, both before and after therapy, and Cx26 to be downregulated [255].

The principle of cell-based (vaccine) therapies relies on activation of B cells and NKT to recognize the specific type of cancer for the case. The basis for a personalized vaccine approach, in which human leukocyte antigen (HLA) molecules on cancer cell surfaces are identified and thus help T cells recognize alterations, has been reviewed recently [261]. A double-blind, placebo-controlled randomized multicentre trial in metastatic castrationresistant prostate cancer patients, in which an autologous active cellular immunotherapy (sipuleucel-T) that targets prostatic acid phosphatase was investigated, revealed a 4-month median survival benefit after 3 years, with no effect on disease progression. The effect of an additional anticancer treatment, applied after the trial, was not prospectively evaluated. In $34.8 \%$ of the cases, adverse events of grade 3 or 4 occurred [262]. The criticisms of the trial that pointed to a lack of specific cell-level data, the fact that older patients in the placebo group appeared to have a shorter survival, and the possibility that the placebo group had a clinically significant age-related survival impact have been addressed recently [263].

Immune-competent cells influence cell migration by cell communication. Chen and Emmens showed that such cells simultaneously influence tumor growth and tumor-associated immune response, accumulate "within the tumor and its locoregional draining lymph nodes" and "these include $\mathrm{CD}^{+} \mathrm{CD} 25^{+} \mathrm{FOXP}^{+}$regulatory $\mathrm{T}$ cells (Tregs), CD4 $4^{+}$interleukin-17producing T helper cells, myeloid-derived suppressor cells (MDSCs), and tumor-associated macrophages (TAMs)" [264]. Since two immunotherapeutic drugs have been approved by the FDA for clinical use in prostate cancer [262] and in advanced melanoma [265], the use of different combinations of chemotherapeutic and immunotherapeutic agents may open new pathways of anticancer treatment and prevention. It would, therefore, be helpful to understand the interactions, within the tumor microenvironment, among the surrounding factors and variables, the cancer cell microenvironment, and, as well, cell-cell communication 
in the context of these immune modulators. The modulation of tumor microenvironment may be of use by increasing the effectiveness of cancer immunotherapy [266].

Within the immune computational network, with all its crosstalk among immunecompetent cells, the signaling paths are incompletely understood. Ferrarelli reviewed the research by McAllister et al. and that of Krycek et al. and pointed out that cytokine signaling pathways released by $\mathrm{T}$ cells affect cancer progression by paracrine cell communication [267-269]. Understanding cell-cell communication, and its underlying mechanisms that allow different cells, compartments, and tissues to regulate and interact, both with each other and with themselves, and over both short as well as long distances, will have an important impact on our knowledge of cancer biology. Research on signaling pathways and cell-communication will be an important field [270]. However, this inquiry may be not enough to advance and nurture the battle against cancer. As commented in our description of a new anticancer strategy [3], the goals may need to be more clearly defined than they have been in this field.

Why do not all cancers respond to immunotherapy treatment? One reason could be that, in the majority of cancers, the cancer cells originate from normal cells, which undergo a transition during the onset of carcinogenesis [2] and, therefore, might not be recognized by the cells of their own immune system, primarily cytotoxic T cells, natural killer cells, lymphokine-activated killer cells, and dendritic cells. Cancer cells do not communicate to the immune system as non-self, or harmful, because they lack the surface structures necessary to tag themselves as bad actors for the immune system. This scenario could explain, also, why cancer immunotherapy is effective in some cancers (e.g. melanomas and prostate cancers) and why competent cell-based therapies (vaccines) have not yet been discovered. For these reasons, immunotherapy should not be expected to provide a unique cure, nor yet can any single anticancer therapy.

\section{(5) Future Aspects of Research in Cell-Cell Communication}

\section{Bioelectrical signaling}

Levin recently reviewed bioelectrical signaling and pointed out that it is "an autonomous layer of control not reducible to a biochemical or genetic account of cell state" [271]. Further, Levin revised the gene-centric paradigm, expanding it, as trans-epithelial electric fields have already been shown to regulate wound healing and the motility of cells [272, 273; reviewed in 271]. The combined network of ion channels, with ion pumps and Connexins generates a plasma membrane resting potential (Vmem) and allows voltage-mediated signaling across cell groups [271]. The Vmem autonomously regulates cell proliferation, differentiation, and apoptosis in somatic cells as well as in stem and cancer cells [reviewed in 271]. The anatomical subcellular components that encode the non-neuronal networks with their bioelectrical code are not fully understood. As our knowledge increases, we may find that bioelectrical networks take a fundamental role in triggering diseases such as cancer. In terms of the recently proposed, new hypothesis for the origin of the majority of cancers, these observations could mean that the proposed primary stimulus, defined as chemical or biological [2], may need to be expanded to include a bioelectrical one as well.

\section{Conclusions}

We have reviewed the mechanisms of cell-cell communication with its anchoring, occluding, and communication junctions, including actual findings in bacteria and on coupling and migration; their influence in the animal and plant kingdoms within the microenvironment and in carcinogenesis; and the underlying cell-cell and sub-cellular communication mechanisms (signaling) of various anticancer treatments. They all will have-together with bioelectrical networks-an impact on future research and on our understanding of cell-cell communication. In the last 30 years, the complexities of biology 
have become ever clearer: We know that genes are not just blueprints that they undergo a bidirectional influence and control, a finding that underlies our contention that mutations also can be caused by an out-to-inside signaling, although that signaling was created somewhere else. Furthermore, it may be myopic to view genes and somatic mutations, single pathways, and single stores of information as under unidirectional control, as every piece in the participating moieties is connected to every other piece. We acknowledge that many aspects of cell-cell communication within the concept of cancer treatment have yet to be elucidated. Socrates's attributed quote, which comes from Plato's Apology, "I know that I know nothing"

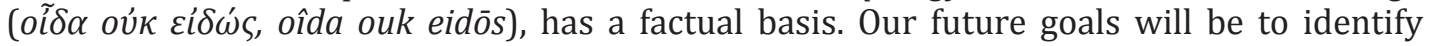
each single orchestrated communication with an understanding of all of the interactions of autocrine and endocrine signaling. The elucidation of such cell-cell communication, locally and globally, can provide an abundance of new targets that could improve the treatment of cancers, offering fewer side effects and better patient outcomes than those we know today.

\section{Abbreviations}

$\alpha$-SMA (alpha smooth muscle actin); Akt (protein kinase B (= PKB) ); ALT (alanine aminotransferase); AMP (adenosine monophosphate); APC(antigen-presenting cell); APOBEC3 (apolipoprotein B mRNA-editing enzyme catalytic polypeptide 3); ATM (Ataxia telangiectasia-mutated kinase); ATR (Rad3-related); bFGF (basic fibroblast growth factor); Bves (blood vessel/epicardial substance); CCl4 (carbon tetrachloride); cdc2kinasis (cyclindependent kinase 2); cGMP (cyclic guanosine monophosphate); CHO (chinese hamster ovary);COX-2 (cyclooxygenase-2 (=Prostaglandin G/H synthetase 2) ); CRB3 (mammalian Crumbs3); CSCs (cancer stem cells); CSES (chronic-stress-escape-strategy); CTC (circulating tumor cell);Cx (Connexin); Cx26 (Connexin26); Cx32 (Connexin32); Cx42 (Connexin 42); Cx43 (Connexin43); CxCL9 (chemokine (C-X-C motif) ligand 9); CxCL12 (stromal cell-derived factor 1 (=SDF-1)); CxCR4 (SDF-1- specific) C-X-C chemokine receptor type 4); CxCR6 (C-X-C chemokine receptor type 6);CxCR6-GFP (C-X-C chemokine receptor type 6 marked with green fluorescent protein); CxHcs (hemichannel (= Hcs)); Cyclin D1 (G1/S-specific Cyclin D1); DSBs (DNA double-strand breaks); ECM(extracellular matrix); EGFR (erpidermal growth factor receptor); EMT (epithelial-mesenchymal transition); ERK (Extracellular signal-related kinase); ERK5 (estrogen receptor 5); FAK (focal adhesion kinase (=PTK2)); FceRI (immunoglobulin E (IgE) receptor); GLUT-1 (glucose transporter 1); GPCR (G-proteincoupled receptor); GSK3beta (glycogen synthase kinase-3beta); GSTs (gluthathione-Stransferase); GTPase (guanosinetriphosphateses);HBV(hepatitis Bvirus); HCC (hepatocelular carcinoma); Hcs (hemichannel $(=\mathrm{CxHcs})$ ); HEI-OC1 (house ear institute organ of corti 1 cells); HLA (human leukocyte antigen); HPC (hemidesmosomes-enriched Protein Complex); HRPT (hypoxanthine guanine phosphoryl transferase); HS (heparin sulphate); HSC (hepatic stellate cell); HSCs (hematopoetic stem cells); HuMIF (human migration inhibitory factor); ICAM-1 (intracellular adhesion molecule 1); IFN- $\alpha$ (interferon alpha); IFN- $\gamma$ (interferon gamma); IGF (insulin growth factor); IGFBP3 (insulin growth factor binding protein-3); IL-2 (interleukin 2); IncRNA (long non-coding RNA); JAK-3 (Janus-activated kinase); JAM (junctional adhesion molecules); LET (linear energy transfer); LMW-PTP (low molecular weight protein tyrosine phosphatase); LOX (lysyl oxidase); Mad (madecassoside);MAP(k) (mitogen-activated protein (kinase)); MaxiK (membrane postassium channel); MC (mast cell); MCP (monocyte chemotactic protein); MET (mesenchymal-epithelial-transition); miRNA (micro RNA); MMP (matrix metalloproteinase); MMP13 (matrix metalloproteinase 13); MRG (PBX-related homeo-box gene MEIS2); mTORC (mechanistic target of rapamycin complex); NAC (N-acetylcysteine); NAFLD (non-alcoholic fatty liver disease); NALP3 (NACHT, LRR and PYD domains-containing protein 3); NASH (nonalcoholic steatohepatitis); NCCCT (normal cell to cancer cell transition); NF- $\mathrm{KB}$ (nuclear factor kappa-light-chain-enhancer of activated B cells); NKT (natural killer T-cells); NMR (nuclear magnetic resonance); OSF (oral submucous fibrosis); p21 (protein 21, cyclin-dependent kinase inhibitor 1 or CDKinteracting protein 1); p38 (protein 38, mitogen-activated protein kinases); p53 (protein 38, tumor protein 53); p85 $\alpha$ (phosphoinositide-3-kinase regulatory subunit 1 (alpha)); p120 (protein 120 (protein of the catenin family)); PANX (Pannexin); PANX1 (Pannexin 1); PANX2 
(Pannexin 2); PANX3 (Pannexin 3); PBX (pre-B-cell leukemia transcription factor); PCN (pre-cancerous niche); PDX1 (pancreatic homeodomain protein); PI3 (phosphoinositide-3 kinase); PKA (protein kinase A); PKB (protein kinase B (= Akt)); PKC (protein-kinase C); PKD1 (ROS-protein kinase C $\delta$ (PKC $\delta$ )-protein kinase D1); PPAR $\gamma$ (peroxisome proliferatoractivated receptor-gamma); PTK2 (focal adhesion kinase (=FAK, =protein tyrosine kinase 2)); PRR (pattern recognition receptors); PTP1B (protein tyrosine phosphatase); PTP1B (protein tyrosine phosphatase); Rac1 (Ras-related C3 botulinum toxin substrate 1); Ras (rat sarcoma protein); RGD (arginine-glycine-aspartate); Rho (Ras homolog gene); RhoA (Ras homolog gene, family, member A); RhoQ (Rho-related GTP-binding protein (= TC10) ); ROS (reactive oxygen species); SDF-1 (stromal cell-derived factor 1 (= CxCL12)); SNP (singlenucleotide polymorphisms); SOD (superoxide dismutase); TAK1/MEK (TGF- $\beta$-activated kinase 1); TAMs (tumor-associated macrophages); TC10 (Rho-related GTP-binding protein); TGF $\beta$ (tumor growth factor beta); TLR (Toll-like receptors); TNF $\alpha$ (tumor necrosis factor alpha); TSIs (templated-sequence insertions); TvMIF (Trichomonas vaginalis macrophage migration inhibitory factor); VCAM (vascular cell adhesion molecule); VDR (vitamin D receptor); VEGFR (vascular endothelial growth factor receptor); Wnt (beta-catenin signaling pathway); ZEB (zinc finger E-box-binding homebox); ZO-1 (tight junction protein).

\section{Disclosure Statement}

Neither author has a competing interest to disclose.

\section{Acknowledgments}

The manuscript was supported by the Theodor-Billroth-Academy® (TBA®) and INCORE, (International Consortium of Research Excellence) of the (TBA®).

\section{References}

1 McCrea PD, Gu D, Balda MS: Junctional music that the nucleus hears: cell-cell contact signaling and the modulation of gene activity. Cold Spring Harb Perspect Biol 2009;1:a002923.

- 2 Brücher BLDM, Jamall JS: Epistemology of the Origin of Cancer: A New Paradigm. BMC Cancer 2014;14:331.

-3 Brücher BLDM, Lyman G, van Hillegersberg R, Pollock RE, Lordick F, Yang HK, Ushijima T, Yeoh KG, Skricka T, Polkowski W, Wallner G, Verwaal V, Garofalo A, D’Ugo D, Roviello F, Steinau HU, Wallace TJ, Daumer M, Maihle N, Reid TJ 3rd, Ducreux M, Kitagawa Y, Knuth A, Zilberstein B, Steele SR, Jamall IS: Imagine a world without cancer. BMC Cancer 2014;14:186.

4 Bauer KH: Mutationstheorie der Geschwulst-Entstehung. Berlin, Julius Springer Verlag, 1928.

-5 Hills CE, Kerr MI, Wall MJ, Squires PE: Visfatin reduces gap junction mediated cell-to-cell communication in proximal tubule-derived epithelial cells. Cell Physiol Biochem 2013;32:1200-1212.

6 Epel BL: Plasmodesmata: composition, structure and trafficking. Plant Mol Biol 1994;26:1343-1356.

7 Loewenstein WR, Kanno Y: Studies on an epithelial (gland) cell junction. I. Modifications of surface membrane permeability. J Cell Biol 1964;22:565-586.

Weidmann S: The electrical constants of Purkinje fibres. J Physiol 1952;118:348-360.

Furshpan EJ, Potter DD: Mechanism of nerve-impulse transmission at a crayfish synapse. Nature 1957;180:342-343.

10 Goodenough DA, Paul DL: Gap junctions. Cold Spring Harb Perspect Biol 2009;1:a0025769.

11 Wiener J, Spiro D, Loewenstein WR: Studies on a epithelial (gland) cell junction. J Cell Biol 1964;22:587598.

12 Loewenstein WR, Kanno Y, Socolar SJ: Quantum jumps of conductance during formation of membrane channels at cell-cell junction. Nature 1978;274:133-136.

13 Brissette JL, Kumar NM, Gilula NB, Hall JE, Dotto GP: Switch in gap junction protein expression is associated with selective changes in junctional permeability during keratinocyte differentiation. Proc Natl Acad Sci USA 1994;91:6453-6457.

14 Peiris TH, Ovieo NJ: Gap junction proteins: Master regulators of the planarian stem cell response to tissue maintenance and injury. Biochim Biophys Acta 2013;1828:109-117. 
15 Furuta K, Lichtenberger R, Helariutta Y: The role of mobile small RNA species during root growth and development. Curr Opin Cell Biol 2012;24:211-216.

-16 Stauffer KA, Kumar NM, Gilula NB, Unwin N: Isolation and purification of gap junction channels J Cell Biol 1991;115:141-150.

17 Goodenough DA: The crystalline lens. A system networked by gap junctional intercellular communication. Semin Cell Biol 1992;3:49-58.

18 Kistler J, Evans C, Donaldson P, Bullivant S, Bond J, Eastwood S, Roos M, Dong Y, Gruijters T, Engel A: Ocular lens gap junctions: protein expression, assembly, and structure-function analysis. Microsc Res Tech 1995;31:347-356.

19 Shibata Y, Kumai M, Nishii K, Nakamura K: Diversity and molecular anatomy of gap junctions. Med Electron Microsc 2001;34:153-159.

20 Sosinsky GE: Image analysis of Gap Junction structures. Electron Microsc Rev 1992;5:59-76.

21 Sosinsky GE, Nicholson BJ: Structural organization of gap junction channels. Biochim Biophys Acat 2005;1711:99-125.

22 Guthrie SC, Gilula NB: Gap junctional communication and development. Trends Neurosci 1989;12:12-16.

-23 Kumar NM, Gilula NB: Molecular biology and genetics of gap junction channels. Semin Cell Biol 1992;3:316.

24 Kumar NM, Gilula NB: The gap junction communication channel. Cell 1996;84:381-388.

25 Larsen WJ, Veenstra RD: Biology of gap junctions. Cell Physiology Source Book. 3rd edition. Academic Press, Elsevier 2001:523-537.

26 Andrysík Z, Procházková J, Kabátková M, Umannová L, Simečková P, Kohoutek J, Kozubík A, Machala M, Vondráček J: Aryl hydrocarbon receptor-mediated disruption of contact inhibition is associated with connexin43 downregulation and inhibition of gap junctional intercellular communication. Arch Toxicol 2013;87:491-503. Watanabe Y: Fine structure of bone marrow stroma. Nihon Ketsueki Gakkai Zasshi 1985;48:1688-1700. Umezawa A, Hata J: Expression of gap-junctional protein (connexin 43 or alpha 1 gap junction) is downregulated at the transcriptional level during adipocyte differentiation of $\mathrm{H}-1 / \mathrm{A}$ marrow stromal cells. Cell Struct Funct 1992;17:177-184.

29 Yeganeh A, Stelmack GL, Fandrich RR, Halayko AJ, Kardami E, Zahradka P: Connexin 43 phosphorylation and degradation are required for adipogenesis. Biochim Biophys Acta 2012;1823:1731-1744.

30 Moore LK, Beyer EC, Burt JM: Characterization of gap junction channels in A7r5 vascular smooth muscle cells. Am J Physiol 1991;260:C975-981.

-31 Oviedo-Orta E, Gasque P, Evans WH: Immunoglobulin and cytokine expression in mixed lymphocyte cultures is reduced by disruption of gap junction intercellular communication. FASEB J 2001;15:768-774.

32 Laird DW: Life cycle of connexins in health and disease. Biochem J 2006;394:527-543.

-33 Paul DL, Ebhara L, Takemoto LJ, Swenson KI, Goodenough DA: Connexin 46, a novel lens gap junftion protein, induces voltage-gates currents in nonjunctional plasma membrane of Xenopus oocytes. J Cell Biol 1991;115:1077-1088.

34 Harris A, Locke D (eds). Connexins: a guide. New York, Springer, 2009.

- 35 Sosinsky G: Mixing of connexins in gap junction membrane channels. Proc Natl Acad Sci USA 1995;92:9210-9214.

-36 Stauffer KA: The gap junction proteins beta 1-connexin (connexin-32) and beta 2-connexin (connexin-26) can form heteromeric hemichannels. J Biol Chem 1995;270:6768-6772.

- 37 Jiang JX, Goodenough DA: Heteromeric connexons in lens gap junction channels. Proc Natl Acad Sci USA 1996;93:1287-1291.

-38 Fallon RF, Goodenough DA: Five-hour half-life of mouse liver gap-junction protein. J Cell Biol 1981;90:521526.

-39 Musil LS, Goodenough DA: Biochemical analysis of connexin43 intracellular transport, phosphorylation, and assembly into gap junctional plaques. J Cell Biol 1991;115:1357-1374.

40 Laird DW, Puranam KL, Revel JP: Turnover and phosphorylation dynamics of connexin43 gap junction protein in cultured cardiac myocytes. Biochem J 1991;273:67-72.

41 Krutovskikh V, Mazzoleni G, Mironov N, Omori Y, Aguelon AM, Mesnil M, Berger F, Partensky C, Yamasaki H: Altered homologous and heterologous gap-junctional intercellular communication in primary human liver tumors associated with aberrant protein localization but not gene mutation of connexin 32. Int J Cancer 1994;56:87-94.

42 Lang F, Föller M, Lang KS, Lang PA, Ritter M, Gulbins E, Vereninov A, Huber SM: Ion channels in cell proliferation and apoptotic cell death. J Membr Biol 2005;205:147-157.

43 Hille B: Ionic channels in excitable membranes. Current problems and biophysical approaches. Biophys J 1978;22:283-294. 
44 Hodgkin AL, Huxley A F: Action Potentials Recorded from Inside a Nerve Fibre. Nature 1939;144:710.

45 Huxley AF, Niedergerke R: Structural changes in muscle during contraction; interference microscopy of living muscle fibres. Nature 1954;173:971-973.

46 Huxley H, Hanson J: Changes in the cross-striations of muscle during contraction and stretch and their structural interpretation". Nature 1954;173:973-976.

47 Neher E, Sakmann B, Steinbach JH: The extracellular patch clamp: a method for resolving currents through individual open channels in biological membranes. Pflugers Archiv 1978;375:219-228

-48 Lang F, Abed M, Lang E, Föller M: Oxidative stress and suicidal erythrocyte death. Antioxid Redox Signal 2014;21:138-153.

49 Yen MR, Saier MH Jr: Gap junctional proteins of animals the innexin/ pannexin superfamily. Prog Biophys Mol Biol 2007;94:5-14.

-50 Sosinsky GE, Boassa D, Dermietzel R, Duffy HS, Laird DW, MacVicar B, Naus CC, Penuela S, Scemes E, Spray DC, Thompson RJ, Zhao HB, Dahl G: Pannexin channels are not gap junction hemichannels. Channels (Austin) 2011;5:193-197.

-51 Ambrosi C, Gassmann O, Pranskevich JN, Boassa D, Smock A, Wang J, Dahl G, Steinem C, Sosinksy GE: Pannexin1 and Pannexin2 channels show quaternary similarities to connexins and different oligomerization numbers from each other. J Biol Chem 2010;285:24420-24431.

-52 Boassa D, Ambrosi C, Qiu F, Dahl G, Gaietta G, Sosinsky G: Pannexin1 channels contain a glycosylation site that targets the hexamer to the plasma membrane. J Biol Chem 2007;282:31733-31743.

53 Pelegrin P, Surprenant A: Pannexin-1 mediates large pore formation and interleukin-1 $\beta$ release by the ATPgated P2X7 receptor. EMBO J 2006;25:5071-5082.

-54 Scanziani E, Grassi F: Purinergic controlof T cell activation by ATP released through pannexin-1 hemichannels. Sci Signal 2008;1:ra6.

55 Locovei S, Bao L, Dahl G: Pannexin 1 in erythrocytes: Function without a gap. Proc Natl Acad Sci USA 2006;103:7655-7659.

-56 Wong CW, Christen T, Roth I, Chadjichristos CE, Derouette JP, Foglia BF, Chanson M, Goodenough DA, Kwak BR: Connexin37 protects against atherosclerosis by regulating monocyte adhesion. Nat Med 2006;12:950954.

Farquahar MG, Palade GE: Junctional complexes in various epithelia. J Cell Biol 1963; 17:375-412. Chalcroft JP, Bullivant S: An interpretation of liver cell membrane and junction structure based on observation of freeze-fracture replicas of both sides of the fracture. J Cell Biol 1970;47:49-60.

59 González-Mariscal L, Betanzos A, Nava P, Jaramillo BE: Tight junction proteins. Prog Biophys Mol Biol 2003;81:1-44.

60 Citi S, Cordenonsi M: Tight junction proteins. Biochim Biophys Acta 1998;1448:1-11.

-61 Stevenson BR, Siliciano JD, Mooseker MS, Goodenough DA: Identification of ZO-1: a high molecular weight polypeptide associated with the tight junction (zonula occludens) in a variety of epithelia. J Cell Biol1986;103:755-766.

62 González-Mariscal L, Tapia R, Chamorro D: Crosstalk of tight junction components with signaling pathways. Biochim Biophys Acta 2008;1778:729-756.

63 Bizzozero G: Le opere scientifi che di Giulio Bizzozero. Introduzione del Prof. Camillo Golgi, 2 vols. Milano: U. Hoepli. 1905.

64 Schaffer J: Vorlesungen über Histologie und Histogenese. Leipzig, W. Engelmann, 1920.

-65 Harmon RM, Green KJ: Structural and functional diversity of desmosomes. Cell Commun Adhes 2013;20:171-187.

66 Halbleib JM, Nelson WJ: Cadherins in development: cell adhesion, sorting, and tissue morphogenesis. Genes Dev 2006;20:3199-3214.

67 Yap AS: The morphogenetic role of cadherin cell adhesion molecules in human cancer: a thematic review. Cancer Invest 1998;16:252-261.

68 Kurrle N, Völlner F, Eming R, Hertl M, Banning A, Tikkanen R: Flotillins Directly Interact with $\gamma$-Catenin and Regulate Epithelial Cell-Cell Adhesion. PLoS One 2013;8:e84393.

69 Jamora C, Fuchs E: Intercellular adhesion, signaling and the cytoskeleton. Nat Cell Biol 2002;4:E101-108.

-70 Müller EJ, Williamson L, Kolly C, Suter MM: Outside in signaling through integrins and cadherins: a central mechanism to control epidermal growth and differentiation? J Invest Dermatol 2008;128:501-516.

71 Gloushankova NA: Changes in regulation of cell-cell adhesion during tumor transformation. Biochemistry (Mosc) 2008;73:742-750.

72 Meng W, Takeichi M: Adherens junction: molecular architecture and regulation. Cold Spring Harb Perspect Biol 2009;1:a002899. 
Brücher/Jamall: Cell-Cell Communication in Carcinogenesis

73 Oda H, Takeichi M: Evolution: structural and functional diversity of cadherin at the adherens junction. J Cell Biol 2011;193:1137-1146.

74 Hu G: p120-Cateinn: a novel regulator of innate immunity and inflammation. Crit Rev Immunol 2012;32:127-138.

75 Legan PK, Collins JE, Garrod DR: The molecular biology of desmosomes and hemidesmosomes: "what's in the name"? Bioessays 1992;14:385-393.

76 Jamora C, DasGupta R, Kocieniewski P, Fuchs E: Links between signal transduction, transcrioption and adhesion in epithelial bud development. Nature 2003;422:317-322.

77 van Norman JM, Breakfield NW, Benfey PN: Intercellular communication during plant development. Plant Cell 2011;23:855-864.

78 Horwitz A, Duggan K, Greggs R, Decker C, Buck C: The cell substrate attachment (CSAT) antigen has properties of a receptor for laminin and fibronectin. J Cell Biol 1986;101:2134-2144.

79 Hynes RO: Integrins: bidirectional, allosteric signaling machines. Cell 2002;110:673-687.

80 Wolfenson H, Lavelin I, Geiger B: Dynamic regulation of the structure and functions of integrin adhesions. Dev Cell 2013;24:447-458.

81 Nermut MV, Green NM, Eason P, Yamada SS, Yamada KM: Electron microscopy and structural model of human fibronectin receptor. EMBO J 1988; 7:4093-4099.

82 Humphries MJ: Integrin structure. Biochem Soc Trans 2000;28:311-339.

83 Marelli UK, Rechenmacher F, Sobahi TR, Mas-Moruno C, Kessler H: Tumor Targeting via Integrin Ligands. Front Oncol 2013;3:222.

84 Suh HN, Han HJ: Fibronectin-induced VEGF receptor and calcium channel transactivation stimulate GLUT-1 synthesis and trafficking through PPAR $\gamma$ and TC10 in mouse embryonic stem cells. Stem Cell Res 2013;10:371-386.

85 Borradori L, Sonnenberg A: Structure and function of hemidesmosomes: more than simpe adhesion complexes. J Investigative Dermatology 1999;112:411-418.

-86 Stanley JR, Hawley-Nelson P, Yuspa SH, Shevach EM, Katz SI: Characterization of bullous pemphigoid antigen: a unique basement membrane protein of stratified squamous epithelia. Cell 1981;24:897-903.

87 Green KJ, Jones JC: Desmosomes and hemidesmosomes: structure and function of molecular components. FASEB J 1996;10:871-881.

88 Stepp MA, Spurr-Michaud S, Gibson IK: Integrins in the wound and unwounded stratified squamous epithelium of the cornea. Invest Ophtalmol Vis Sci 1993;34:1829-1844.

-89 Rezniczek GA, de Pereda JM, Reipert S, Wiche G: Linking integrin alpha6beta4-based cell adhesion to the intermediate filament cytoskeleton: direct interaction between the beta4 subunit and plectin at multiple molecular sites. J Cell Biol 1998;141:209-225.

90 Ozawa T, T, Tsuruta D, Jones JC, Ishii M, Ikeda K, Harada T, Aoyama Y, Kawada A, Kobayashi H: Dynamic relationship of focal contacts and hemidesmosome protein complexes in live cells. J Invest Dermatol 2010;130:1624-35

-91 Madigan MC, Holden BA: Reduced epithelial adhesion after extended contact lens wear correlates with reduced hemidesmosome density in cat cornea. Invest Ophthalmol Vis Sci 1992;33:314-323.

$\$ 92$ Chi C, Trinkaus-Randall V: New insights in wound response and repair of epithelium. J Cell Physiol 2013;228:925-929.

-93 Dowling J, Yu Q-C, Fuchs E: $\beta 4$ integrin is required for hemidesmosome formation, cell adhesion and cell survival. J Cell Biol 1996;134:559-572.

94 Chiarugi P: Reactive oxygen species as mediators of cell adhesion. Ital J Biochem 2003;52:28-32.

-95 Sawhney RS, Liu W, Brattain MG: A novel role of ERK5 in integrin-mediated cell adhesion and motility in cancer cells via FAK signaling. J Cell Physiol 2009;219:152-160.

-96 Yousif NG: Fibronectin promotes migration and invasion of ovarian cancer cells through up-regulation of FAK-PI3K/Akt pathway. Cell Biol Int 2014;38:85-91.

-97 Wang P, Han L, Shen H, Wang P, Lv C, Zhao G, Niu J, Xue L, Wang QJ, Tong T, Chen J: Protein kinase D1 is essential for Ras-induced senescence and tumor suppression by regulating senescence-associated inflammation. Proc Natl Acad Sci USA 2014;111:7683-7688.

$\$ 98$ Guterres FA, Martinez GR, Rocha ME, Winnischofer SM: Simvastatin rises reactive oxygen species levels and induces senescence in human melanoma cells by activation of p53/p21 pathway. Exp Cell Res 2013;319:2977-1988.

-99 Knösel T, Altendorf-Hofmann A, Lindner L, Issels R, Hermeking H, Schuebbe G, Gibis S, Siemens H, Kampmann E, Kirchner T: Loss of p16(INK4a) is associated with reduced patient survival in soft tissue tumours, and indicates a senescence barrier. J Clin Pathol 2014;67:592-598. 
Brücher/Jamall: Cell-Cell Communication in Carcinogenesis

100 Taniguchi Ishikawa E1, Gonzalez-Nieto D, Ghiaur G, Dunn SK, Ficker AM, Murali B, Madhu M, Gutstein DE, Fishman GI, Barrio LC, Cancelas JA: Connexin-43 prevents hematopoietic stem cell senescence through transfer of reactive oxygen species to bone marrow stromal cells. Proc Natl Acad Sci USA 2012;109:90719076.

101 Ben-Jacob E, Levine H: Self-engineering capabilities in bacteria. J R Soc Interface 2006;3:197-214.

102 Taga ME, Bassler BL: Chemical communication among bacteria. Proc Natl Acad Sci USA 2003;100:1454914554.

103 Farghaly AH: Factors influencing the growth and light production of luminous bacteria. J Cell Comp Physiol 1950;36:165-184.

104 Hastings JW1, Greenberg EP: Quorum sensing: the explanation of a curious phenomenon reveals a common characteristic of bacteria. J Bacteriol 1999;181:2667-2668.

105 Fuqua WC, Winans SC, Greenberg EP: Quorum sensing in bacteria: the LuxR-LuxI family of cell densityresponsive transcriptional regulators. J Bacteriol 1994;176:269-275.

106 Anderson WAD (ed). Pathology, Volume One, 6th edition, St. Louis, The CV Mosby Company, 1971.

107 Rosenfeld S: Are the somatic mutation and tissue organization field theories of carcinogenesis incompatible? Cancer Inform 2013;12:221-229.

108 Matveev V: What is your opinion on this paper? Researchgate 2014: https://www.researchgate.net/post/ What_is_your_opinion_on_this_paper.

109 Krawczyk M, Emerson BM: p50-associated COX-2 extragenic RNA (PACER) activates COX-2 gene expression by occluding repressive NF- $\kappa$ B complexes. Elife 2014;3:e01776.

110 Porter KR, Kallman FL: Significance of cell particulates as seen by electron microscopy. Ann N Y Acad Sci 1952;54:882-891.

111 Porter KR: Observations on a submicroscopic basophilic component of cytoplasm. J Exp Med 1953;97:727750 .

112 Fawcett DW: The membranes of the cytoplasm. Lab Invest 1961;10:1162-1188.

113 Halemano K, Guo K, Heilman KJ, Barrett BS, Smith DS, Hasenkrug KJ, Santiago ML: Immunoglobulin somatic hypermutation by APOBEC3/Rfv3 during retroviral infection. Proc Natl Acad Sci USA 2014;111:7759-7764.

114 Onozawa M, Zhang Z, Kim YJ, Goldberg L, Varga T, Bergsagel PL, Kuehl WM, Aplan PD: Repair of DNA double-strand breaks by templated nucleotide sequence insertions derived from distant regions of the genome. Proc Natl Acad Sci USA 2014;111:7729-7734.

115 WangY, Mehta PP: Facilitation of gap-junctional communication and gap-junction formation in mammalian cells by inhibition of glycosylation. Eur J Cell Biol 1995;67:285-296.

116 Garber SA, Fernstrom MJ, Stoner GD, Ruch RJ: Altered gap junctional intercellular communication in neoplastic rat esophageal epithelial cells. Carcinogenesis 1997;18:1149-1153.

117 Figueroa XF, Duling BR: Gap junctions in the control of vascular function. Antioxid Redox Signal 2009;11:251-266.

118 Qazi H, Palomino R, Shi ZD, Munn LL, Tarbell JM: Cancer cell glycocalyx mediates mechanotransduction and flow-regulated invasion. Integr Biol (Camb) 2013;5(11):1334-1343.

119 Hunter J: A treatise on the blood, inflammation and gunshot wounds. London: Nichol G, P 531, 1794.

120 Oort J, Scheper RJ: Histopathology of acute and chronic inflammation. Agents Actions Suppl 1977;3:25-30.

121 Coffelt SB, de Visser KE: Cancer: Inflammation lights the way to metastasis. Nature 2014;507:48-49.

122 Vliagoftis H, Hutson AM, Mahmudi-Azer S, Kim H, Rumsaeng V, Oh CK, Moqbel R, Metcalfe DD: Mast cells express connexins on their cytoplasmic membrane. J Allergy Clin Immunol 1999;103:656-662.

123 Eugenin EA, Branes MC, Berman JW, Saez JC: TNF-alpha plus IFN-gamma induce connexin43 expression and formation of gap junctions between human monocytes/macrophages that enhance physiological responses. J Immunol 2003;170:1320-1328.

124 Jara PI, Boric MP, Saez JC: Leukocytes express connexin 43 after activation with lipopolysaccharide and appear to form gap junctions with endothelial cells after ischemia-reperfusion. Proc Natl Acad Sci USA 1995;92:7011-7015.

125 Xia Y, Jin X, Yan J, Entman ML, Wang Y: CXCR6 Plays a Critical Role in Angiotensin II-Induced Renal Injury and Fibrosis. Arterioscler Thromb Vasc Biol 2014.May 22.[Epub ahead of print].

$\$ 126$ Oliveira AM, Ross JS, Fletcher JA: Tumor suppressor genes in breast cancer: the gatekeepers and the caretakers. Am J Clin Pathol 2005;124:S16-28.

127 Chetram MA, Don-Salu-Hewage AS, Hinton CV: ROS enhances CXCR4-mediated functions through inactivation of PTEN in prostate cancer cells. Biochem Biophys Res Commun 2011;410:195-200.

128 Gingery A1, Bradley EW, Pederson L, Ruan M, Horwood NJ, Oursler MJ: TGF-beta coordinately activates TAK1/MEK/AKT/NFkB and SMAD pathways to promote osteoclast survival. Exp Cell Res 2008;314:27252738. 
129 Matsuura I, Denissova NG, Wang G, He D, Long J, Liu F: Cyclin-dependent kinases regulate the antiproliferative function of Smads. Nature 2004;430:226-231.

130 Dai C, Yang J, Liu Y: Transforming growth factor-beta1 potentiates renal tubular epithelial cell death by a mechanism independent of Smad signaling. J Biol Chem 2003;278:12537-12545.

131 Edlund S, Bu S, Schuster N, Aspenström P, Heuchel R, Heldin NE, ten Dijke P, Heldin CH, Landström M: Transforming growth factor-beta1 (TGF-beta)-induced apoptosis of prostate cancer cells involves Smad7dependent activation of $\mathrm{p} 38$ by TGF-beta-activated kinase 1 and mitogen-activated protein kinase kinase 3. Mol Biol Cell 2003;14:529-544.

132 Yoo J, Ghiassi M, Jirmanova L, Balliet AG, Hoffman B, Fornace AJ Jr, Liebermann DA, Bottinger EP, Roberts AB: Transforming growth factor-beta-induced apoptosis is mediated by Smad-dependent expression of GADD45b through p38 activation. J Biol Chem 2003;278:43001-43007.

133 Kim KY, Kim BC, Xu Z, Kim SJ: Mixed lineage kinase 3 (MLK3)-activated p38 MAP kinase mediates transforming growth factor-beta-induced apoptosis in hepatoma cells. J Biol Chem 2004;279:2947829484.

134 Landström M, Heldin NE, Bu S, Hermansson A, Itoh S, ten Dijke P, Heldin CH: Smad7 mediates apoptosis induced by transforming growth factor beta in prostatic carcinoma cells. Curr Biol 2000;10:535-538.

135 Mazars A, Lallemand F, Prunier C, Marais J, Ferrand N, Pessah M, Cherqui G, Atfi A: Evidence for a role of the JNK cascade in Smad7-mediated apoptosis. J Biol Chem 2001;276:36797-36803.

136 Townsend DM, Tew KD: The role of glutathione-S-transferase in anti-cancer drug resistance. Oncogene 2003;22:7369-7375.

137 Cullen KJ, Newkirk KA, Schumaker LM, Aldosari N, Rone JD, Haddad BR: Glutathione S-transferase pi amplification is associated with cisplatin resistance in head and neck squamous cell carcinoma cell lines and primary tumors. Cancer Res 2003;63:8097-8102.

138 Twu O, Dessí D, Vu A, Mercer F, Stevens GC, de Miguel N, Rappelli P, Cocco AR, Clubb RT, Fiori PL, Johnson PJ: Trichomonas vaginalis homolog of macrophage migration inhibitory factor induces prostate cell growth, invasiveness, and inflammatory responses. Proc Natl Acad Sci USA 2014;111:8179-8184.

-139 Henderson NC, Arnold TD, Katamura Y, Giacomini MM, Rodriguez JD, McCarty JH, Pellicoro A, Raschperger E, Betsholtz C, Ruminski PG, Griggs DW, Prinsen MJ, Maher JJ, Iredale JP, Lacy-Hulbert A, Adams RH, Sheppard D: Targeting of $\alpha v$ integrin identifies a core molecular pathway that regulates fibrosis in several organs. Nat Med 2013;19:1617-1624.

140 Chen J, Xia Y, Lin X, Feng XH, Wang Y: Smad3 signaling activates bone marrow-derived fibroblasts in renal fibrosis. Lab Invest 2014;94:545-556.

141 Shen X, Hu PP, Liberati NT, Datto MB, Frederick JP, Wang XF: TGF-beta-induced phosphorylation of Smad3 regulates its interaction with coactivator p300/CREB-binding protein. Mol Biol Cell 1998;9:3309-3319.

142 Wang G, Matsuura I, He D, Liu F: Transforming growth factor-\{beta\}-inducible phosphorylation of Smad3. J Biol Chem 2009;284:9663-9673.

143 Lu GX, Bian DF, Ji Y, Guo JM, Wei ZF, Jiang SD, Xia YF, Dai Y: Madecassoside Ameliorates Bleomycin-Induced Pulmonary Fibrosis in Mice by Downregulating Collagen Deposition. Phytother Res doi: 10.1002/ptr.5120.

144 Ding N, Yu RT, Subramaniam N, Sherman MH, Wilson C, Rao R, Leblanc M, Coulter S, He M, Scott C, Lau SL, Atkins AR, Barish GD, Gunton JE, Liddle C, Downes M, Evans RM: A vitamin D receptor/SMAD genomic circuit gates hepatic fibrotic response. Cell 2013;153:601-613.

145 Friedman SL, Roll FJ, Boyles J, Bissell DM: Hepatic lipocytes: the principal collagen-producing cells of normal rat liver. Proc Natl Acad Sci USA 1985;82:8681-8685.

146 Yokoi Y, Namihisa T, Kuroda H, Komatsu I, Miyazaki A, Watanabe S, Usui K: Immunocytochemical detection of desmin in fat-storing cells (Ito cells). Hepatology 1984;4:709-714.

147 Mayne R, Vail MS, Miller EJ: Characterization of the collagen chains synthesized by cultured smooth muscle cells derived from rhesus monkey thoracic aorta. Biochemistry 1978;17:446-452.

148 Lazarides E: Intermediated filaments as mechanical integrators of cellular space. Nature 1980;283:249256.

149 Winau F, Hegasy G, Weiskirchen R, Weber S, Cassan C, Sieling PA, Modlin RL, Liblau RS, Gressner AM, Kaufmann SH: Ito cells are liver-resident antigen-presenting cells for activating $\mathrm{T}$ cell responses. Immunity 2007;26:117-129.

150 Vivier E, Raulet DH, Moretta A, Caligiuri MA, Zitvogel L, Lanier LL, Yokoyama WM, Ugolini S: Innate or adaptive immunity? The example of natural killer cells. Science 2011;331:44-49.

151 Scheper W, Gründer C, Straetemans T, Sebestyen Z, Kuball J: Hunting for clinical translation with innate-like immune cells and their receptors. Leukemia 2014;28:1181-1190.

152 Parham P: MHC class I molecules and KIRs in human history, health and survival. Nat Rev Immunol 2005;5:201-214. 
153 Tittarelli A, Mendoza-Naranjo A, Farías M, Guerrero I, Ihara F, Wennerberg E, Riquelme S, Gleisner A, Kalergis A, Lundqvist A, López MN, Chambers BJ, Salazar-Onfray F: Gap junction intercellular communications regulate NK cell activation and modulate NK cytotoxic capacity. J Immunol 2014;192:1313-1319.

154 Henderson NC, Sheppard D: Integrin-mediated regulation of TGFbeta in fibrosis. Biochim Biophys Acta 2013;1832:891-896.

155 Fausther M, Lavoie EG, Dranoff JA: Contribution of Myofibroblasts of Different Origins to Liver Fibrosis. Curr Pathobiol Rep 2013;1:225-230.

156 Harms JF, Welch DR, Samant RS, Shevde LA, Miele ME, Babu GR, Goldberg SF, Gilman VR, Sosnowski DM, Campo DA, Gay CV, Budgeon LR, Mercer R, Jewell J, Mastro AM, Donahue HJ, Erin N, Debies MT, Meehan WJ, Jones AL, Mbalaviele G, Nickols A, Christensen ND, Melly R, Beck LN, Kent J, Rader RK, Kotyk JJ, Pagel MD, Westlin WF, Griggs DW: A small molecule antagonist of the alpha(v)beta3 integrin suppresses MDAMB-435 skeletal metastasis. Clin Exp Metastasis 2004;21:119-128.

157 Deng YR, Yoshida K, Jin QL, Murata M, Yamaguchi T, Tsuneyama K, Moritoki Y, Niu JQ, Matsuzaki K, Lian ZX: Reversible phospho-Smad3 signaling between tumour suppression and fibrocarcinogenesis in chronic hepatitis B infection. Clin Exp Immunol 2014;176:102-111.

158 De Minicis S, Rychlicki C, Agostinelli L, Saccomanno S, Candelaresi C, Trozzi L, Mingarelli E, Facinelli B, Magi G, Palmieri C, Marzioni M, Benedetti A, Svegliati-Baroni G: Dysbiosis contributes to fibrogenesis in the course of chronic liver injury in mice. Hepatology 2014;59:1738-1749.

159 Yang L, Kwon J, Popov Y, Gajdos GB, Ordog T, Brekken RA, Mukhopadhyay D, Schuppan D, Bi Y, Simonetto D, Shah VH: Vascular endothelial growth factor promotes fibrosis resolution and repair in mice. Gastroenterology 2014;146:1339-1350.e1.

160 Shattil SJ, Kim C, Ginsberg MH: The final steps of integrin activation: the end game. Nat Rev Mol Cell Biol 2010;11:288-300.

161 Box C, Rogers SJ, Mendiola M, Eccles SA: Tumour-microenvironmental interactions: paths to progression and targets for treatment. Semin Cancer Biol 2010;20:128-138.

162 Yu Y, Shi X, Shu Z, Xie T, Huang K, Wei L, Song H, Zhang W, Xue X: Stromal Cell-Derived Factor-1 (SDF-1)/ CXCR4 Axis Enhances Cellular Invasion in Ovarian Carcinoma Cells Via Integrin $\beta 1$ and $\beta 3$ Expressions. Oncol Res 2014;21:217-225.

163 Wang B, Wang W, Niu W, Liu E, Liu X, Wang J, Peng C, Liu S, Xu L, Wang L, Niu J: SDF-1/CXCR4 axis promotes directional migration of colorectal cancer cells through upregulation of integrin $\alpha v \beta 6$. Carcinogenesis 2014;35:282-291.

164 Sun X, Cheng G, Hao M, Zheng J, Zhou X, Zhang J, Taichman RS, Pienta KJ, Wang J: CXCL12/CXCR4/CXCR7 Chemokine Axis and Cancer Progression. Cancer Metastasis Rev 2010;29:709-722.

165 Madsen CD, Sahai E: Cancer Dissemination - Lessens from Leukocytes. Dev Cell 2010;19:13-26.

166 Moharita AL, Taborga M, Corcoran KE, Bryan M, Patel PS, Rameshwar P: SDF-1alpha regulation in breast cancer cells contacting bone marrow stroma is critical for normal hematopoiesis. Blood 2006;108:32453252.

167 Pritchett J, Wright C, Zeef L, Nadarajah B: Stromal derived factor-1 exerts differential regulation on distinct cortical cell populations in vitro. BMC Dev Biol 2007; 7:31.

168 Cavanagh JF, Mione MC, Pappas IS, Parnavelas JG: Basic fibroblast growth factor prolongs the proliferation of rat cortical progenitor cells in vitro without altering their cell cycle parameters. Cereb Cortex 1997; 7:293-302.

169 Yi T, Zhai B, Yu Y, Kiyotsugu Y, Raschle T, Etzkorn M, Seo HC, Nagiec M, Luna RE, Reinherz EL, Blenis J, Gygi SP, Wagner G: Quantitative phosphoproteomic analysis reveals system-wide signaling pathways downstream of SDF-1/CXCR4 in breast cancer stem cells. Proc Natl Acad Sci USA 2014;111:E2182-2190.

170 Wolf J, Dewi DL, Fredebohm J, Müller-Decker K, Flechtenmacher C, Hoheisel JD, Boettcher M: A mammosphere formation RNAi screen reveals that ATG4A promotes a breast cancer stem-like phenotype. Breast Cancer Res 2013;15:R109.

171 Cox TT, Bird D, Baker AM, Barker HE, Ho MW, Lang G, Erler JT: LOX-mediated collagen crosslinking is responsible for fibrosis-enhanced metastasis. Cancer Res 2013;73:1721-1732

172 Manov I, Hirsh M, Iancu TC, Malik A, Sotnichenko N, Band M, Avivi A, Shams I: Pronounced cancer resistance in a subterranean rodent, the blind mole-rat, Spalax: in vivo and in vitro evidence. BMC Biology 2013;11:91.

173 Tian X, Azpurua J, Hine C, Vaidya A, Myakishev-Rempel M, Ablaeva J, Mao Z, Nevo E, Gorbunova V, Seluanov A: High-molecular-mass hyaluronan mediates the cancer resistance of the naked mole rat. Nature 2013;499:346-349.

174 Minami K, Miyawaki K, Hara M, Yamada S, Seino S: Tracing phenotypic reversibility of pancreatic $\beta$-cells in vitro. J Diabetes Investig 2010;1:242-251. 
Brücher/Jamall: Cell-Cell Communication in Carcinogenesis

175 Zeng Y, Tarbell JM: The adaptive remodeling of endothelial glycocalyx in response to fluid shear stress. PLoS One 2014;9:e86249

176 Slavkin HC, Greulich RC (eds): Extracellular Matrix Influences on Gene Expression. Academic Press, Inc, New York Academic 1975, P833.

177 Mecham RP, Madaras JG, Senior RM: Extracellular matrix-specific induction of elastogenic differentiation and maintenance of phenotypic stability in bovine ligament fibroblasts. J Cell Biol 1984;98:1804-1812.

178 Zhe X, Cher ML, Bonfil RD: Circulating tumor cells: finding the needle in the haystack. Am J Cancer Res 2011;1:740-751.

179 Fidler JJ: Metastasis: guantitative analysis of distribution and fate of tumor embolilabeled with 125 I-5iodo-2'-deoxyuridine. J Natl Cancer Inst 1970;45:773-782.

180 Stoka AM: Phylogeny and evolution of chemical communication: an endocrine approach. J Mol Endoccrinol 1999;22:207-225.

181 Bonner JT, Sieja TW, Hall EM: Further evidence for the sorting out of cells in the differentiation of the cellular slime mold Dictyostelium. J Embryol Exp Morphol 1971;25:457-465.

182 Vallesi A, Giuli G, Bradshaw RA, Luporini P: Autocrine mitogenic activity of pheromones produced by the protozanciliate Euplotes raikovi. Nature 1995;376:522-524.

183 Coutinho P, Qiu C, Frank S, Tamber K, Becker D: Dynamic changes in connexin expression correlate with key events in the wound healing process. Cell Biol Int 2003;27:525-541.

184 Scemes E, Spray DC, Meda P: Connexins, pannexins, innexins: novel roles of "hemi-channels". Pflugers Arch 2009;457:1207-1226.

185 Kardami E, Dang X, Iacobas DA, Nickel BE, Jeyaraman M, Srisakuldee W, Makazan J, Tanguy S, Spray DC: The role of connexins in controlling cell growth and gene expression. Prog Biophys Mol Biol 2007;94:245-264.

186 Leithe E, Sirnes S, Omori Y, Rivedal E: Downregulation of gap junctions in cancer cells. Crit Rev Oncog 2006;12:225-256.

187 Pointis G, Fiorini C, Gilleron J, Carette D, Segretain D: Connexins as precocious markers and molecular targets for chemical and pharmacological agents in carcinogenesis.Curr Med Chem 2007;14:2288-2303.

188 Formenti SC, Demaria S: Combining radiotherapy and cancer immunotherapy: a paradigm shift. J Natl Cancer Inst 2013;105:256-265.

189 Vaiyapuri S, Jones CI, Sasikumar P, Moraes LA, Munger SJ, Wright JR, Ali MS, Sage T, Kaiser WJ, Tucker KL, Stain CJ, Bye AP, Jones S, Oviedo-Orta E, Simon AM, Mahaut-Smith MP, Gibbins JM: Gap Junctions and Connexin Hemichannels Underpin Haemostasis and Thrombosis. Circulation 2012;125:2479-2491.

190 Bermudez-Fajardo A, Yliharsila M, Evans WH, Newby AC, Oviedo-Orta E: CD4+ T lymphocyte subsets express connexin 43 and establish gap junction channel communication with macrophages in vitro. J Leukoc Biol 2007;82:608-612.

191 Mesnil M: Connexins and cancer. Biol Cell 2002;94:493-500.

192 Tsai H, Werber J, Davia MO, Edelman M, Tanaka KE, Melman A, Christ GJ, Geliebter J: Reduced connexin 43 expression in high grade, human prostatic adenocarcinoma cells. Biochem Biophys Res Commun 1996;227:64-69.

193 Chen JT, Cheng YW, Chou MC, Sen-Lin T, Lai WW, Ho WL, Lee H: The correlation between aberrant connexin 43 mRNA expression induced by promoter methylation and nodal micrometastasis in non-small cell lung cancer. Clin Cancer Res 2003;9:4200-4204.

194 Zhang W, Li HG, Fan MJ, Lv ZQ Shen XM, He XX: Expressions of connexin 32 and 26 and their correlation to prognosis of non-small cell lung cancer. Ai Zheng 2009;28:173-176.

195 Lin Z, Zhang Z, Wang N: [Inhibition of in vivo growth of lung carcinoma cells after transfection with gap junction gene Cx43]. Zhonghua Zhong Liu Za Zhi 1997;19:253-255.

196 Mehta PP, Perez-Stable C, Nadji M, Mian M, Asotra K, Roos BA: Suppression of human prostate cancer cell growth by forced expression of connexin genes. Dev Genet 1999;24:91-110.

197 Moorby C, Patel M: Dual functions for connexins: Cx43 regulates growth independently of gap junction formation. Exp Cell Res 2001;271:238-248.

198 Koffler LS, Roshong S, Kyu Park I, Cesen-Cummings K, Thompson DC, Dwyer-Nield LD, Rice P, Mamay C, Malkinson AM, Ruch RJ: Growth inhibition in G(1) and altered expression of cyclin D1 and p27(kip-1) after forced connexin expression in lung and liver carcinoma cells. J Cell Biochem 2000;79:347-354.

199 Loncarek J, Yamasaki H, Levillain P, Milinkevitch S, Mesnil M: The expression of the tumor suppressor gene connexin 26 is not mediated by methylation in human esophageal cancer cells. Mol Carcinog 2003;36:7481.

200 Tan LW, Bianco T, Dobrovic A: Variable promoter region CpG island methylation of the putative tumor suppressor gene Connexin 26 in breast cancer. Carcinogenesis 2002;23:231-236.

201 Simon KW, Roberts PC, Vespremi MJ, Manchen S, Schmelz EM: Regulation of beta-catenin and connexin-43 expression: targets for sphingolipids in colon cancer prevention. Mol Nutr Food Res 2009;53:332-340. 
Brücher/Jamall: Cell-Cell Communication in Carcinogenesis

202 Zhang Y, Xu H, Wang E: [Expressions of connexin 43 and E-cadherin and their correlation in non-small cell lung cancer]. Zhongguo Fei Ai Za Zhi 2005;8:103-106.

-203 Arregui CO, González A, Burdisso JE, González Wusener AE: Protein tyrosine phosphatase PTP1B in cell adhesion and migration. Cell Adh Migr 2013;7:418-23.

204 Nagasawa H, Little JB: Induction of sister chromatid exchanges by extremely low doses of alpha-particles. Cancer Res 1992;52:6394-6396.

205 Wu LJ, Randers-Pehrson G, Xu A, Waldren CA, Geard CR, Yu Z, Hei TK: Targeted cytoplasmic irradiation with alpha particles induces mutations in mammalian cells. Proc Natl Acad Sci USA 1999;96:4959-4964.

206 Shao C, Stewart V, Folkard M, Michael BD, Prise KM: Nitric oxide-mediated signaling in the bystander response of individually targeted glioma cells. Cancer Res 2003;63:8437-8342.

207 Mothersill C, Seymour CB: Cell-cell contact during gamma irradiation is not required to induce a bystander effect in normal human keratinocytes: evidence for release during irradiation of a signal controlling survival into the medium. Radiat Res 1998;149:256-262.

208 Hamada N, Maeda M, Otsuka K, Tomita M: Signaling pathways underpinning the manifestations of ionizing radiation-induced bystander effects. Curr Mol Pharmacol 2011;4:79-95.

209 Azzam EI, de Toledo SM, Little JB: Direct evidence for the participation of gap junction-mediated intercellular communication in the transmission of damage signals from alpha -particle irradiated to nonirradiated cells. Proc Natl Acad Sci USA 2001;98:473-478.

210 Persaud R, Zhou H, Baker SE, Hei TK, Hall EJ: Assessment of low linear energy transfer radiation-induced bystander mutagenesis in a three-dimensional culture model. Cancer Res 2005;65:9876-9882.

-211 Seymour CB, Mothersill C: Delayed expression of lethal mutations and genomic instability in the progeny of human epithelial cells that survived in a bystander-killing environment. Radiat Oncol Investig 1997;5:106110.

212 Nagar S, Smith LE, Morgan WF: Characterization of a novel epigenetic effect of ionizing radiation: the death-inducing effect. Cancer Res 2003;63:324-328.

213 Lewis DA, Mayhugh BM, Qin Y, Trott K, Mendonca MS: Production of delayed death and neoplastic transformation in CGL1 cells by radiation-induced bystander effects. Radiat Res 2001;156:251-258.

214 Heuskin AC, Wéra AC, Riquier H, Michiels C, Lucas S: Low-dose hypersensitivity and bystander effect are not mutually exclusive in A549 lung carcinoma cells after irradiation with charged particles. Radiat Res 2013;180:491-498.

-215 Lin YF, Nagasawa H, Little JB, Kato TA, Shih HY, Xie XJ, Wilson PF Jr, Brogan JR, Kurimasa A, Chen DJ, Bedford JS, Chen BP: Differential radiosensitivity phenotypes of DNA-PKcs mutations affecting NHEJ and HRR systems following irradiation with gamma-rays or very low fluences of alpha particles. PLoS One 2014;9:e93579.

-216 Zhou H, Ivanov VN, Gillespie J, Geard CR, Amundson SA, Brenner DJ, Yu Z, Lieberman HB, Hei TK: Mechanism of radiation-induced bystander effect: role of the cyclooxygenase- 2 signaling pathway. Proc Natl Acad Sci USA 2005;102:14641-14646.

217 Hei TK, Zhou H, Chai Y, Ponnaiya B, Ivanov VN: Radiation induced non-targeted response: mechanism and potential clinical implications. Curr Mol Pharmacol 2011;4:96-105.

218 Bakkenist CJ, Kastan MB: DNA damage activates ATM through intermolecular autophosphorylation and dimer dissociation. Nature 2003;421:499-506.

219 Matsuoka S, Ballif BA, Smogorzewska A, McDonald ER 3rd, Hurov KE, Luo J, Bakalarski CE, Zhao Z, Solimini N, Lerenthal Y, Shiloh Y, Gygi SP, Elledge SJ: ATM and ATR substrate analysis reveals extensive protein networks responsive to DNA damage. Science 2007;316:1160-1166.

220 Lee JH, Paull TT: Activation and regulation of ATM kinase activity in response to DNA double-strand breaks. Oncogene 2007;26:7741-7748.

221 Rashi-Elkeles S, Elkon R, Weizman N, Linhart C, Amariglio N, Sternberg G, Rechavi G, Barzilai A, Shamir $\mathrm{R}$, Shiloh Y: Parallel induction of ATM-dependent pro- and antiapoptotic signals in response to ionizing radiation in murine lymphoid tissue. Oncogene 2006;25:1584-1592.

222 Burdak-Rothkamm S, Rothkamm K, Prise KM: ATM acts downstream of ATR in the DNA damage response signaling of bystander cells. Cancer Res 2008;68:7059-7065.

223 Ivanov VN, Zhou H, Ghandhi SA, Karasic TB, Yaghoubian B, Amundson SA, Hei TK: Radiation-induced bystander signaling pathways in human fibroblasts: a role for interleukin-33 in the signal transmission. Cell Signal 2010;22:1076-1087.

224 Ghandhi SA, Yaghoubian B, Amundson SA: Global gene expression analyses of bystander and alpha particle irradiated normal human lung fibroblasts: synchronous and differential responses. BMC Med Genomics 2008;1:63. 
Brücher/Jamall: Cell-Cell Communication in Carcinogenesis

225 Zhang Y, Zhou J, Held KD, Redmond RW, Prise KM, Liber HL: Deficiencies of double-strand break repair factors and effects on mutagenesis in directly gamma-irradiated and medium-mediated bystander human lymphoblastoid cells. Radiat Res 2008;169:197-206.

226 Aravindan N, Aravindan S, Pandian V, Khan FH, Ramraj SK, Natt P, Natarajan M. Acquired tumor cell radiation resistance at the treatment site is mediated through radiation-orchestrated intercellular communication. Int J Radiat Oncol Biol Phys 2014;88:677-685.

227 Grivennikov SI1, Karin M: Dangerous liaisons: STAT3 and NF-kappaB collaboration and crosstalk in cancer. Cytokine Growth Factor Rev 2010;21:11-19.

228 Zhou H, Ivanov VN, Lien YC, Davidson M, Hei TK: Mitochondrial function and nuclear factor-kappaBmediated signaling in radiation-induced bystander effects. Cancer Res 2008;68:2233-2240.

229 Grivennikov S, Karin E, Terzic J, Mucida D, Yu GY, Vallabhapurapu S, Scheller J, Rose-John S, Cheroutre H, Eckmann L, Karin M: IL-6 and Stat3 are required for survival of intestinal epithelial cells and development of colitis-associated cancer. Cancer Cell 2009;15:103-113.

230 Chargari C, Clemenson C, Martins I, Perfettini JL, Deutsch E: Understanding the functions of tumor stroma in resistance to ionizing radiation: emerging targets for pharmacological modulation. Drug Resist Updat 2013;16:10-21.

231 Philips FS, Gilman A: Water and electrolyte balance in dogs intoxicated with nitrogen mustard. Am J Physiol 1948;155:295-308.

232 Farber S, Diamond LK: Temporary remissions in acute leukemia in children produced by folic acid antagonist, 4-aminopteroyl-glutamic acid. N Engl J Med 1948; 238:787-793.

233 Philips FS, Thiersch JB: Actions of 2,6-diaminopurine in mice, rats, and dogs. Proc Soc Exp Biol Med 1949;72:401-408.

234 Thiersch JB, Philips FS: Folic acid and antagonists in neoplastic disease. Am J Med Sci 1949;217:575-585.

235 Galmarini D, Galmarini CM, Galmarini FC: Cancer chemotherapy: a critical analysis of its 60 years of history. Crit Rev Oncol Hematol 2012;84:181-199.

236 Mahmud H, Föller M, Lang F: Suicidal erythrocyte death triggered by cisplatin. Toxicology 2008;249:40-44.

237 Qiu C, Coutinho P, Frank S, Franke S, Law L-Y, Martin P, Green CR, Becker DL: Targeting Connexin43 Expression Accelerates the Rate of Wound Repair. Curr Biol 2003;13:1697-1703.

-238 Zhang J, O'Carroll SJ, Henare K, Ching LM, Ormonde S, Nicholson LF, Danesh-Meyer HV, Green CR: Connexin hemichannel induced vascular leak suggests a new paradigm for cancer therapy. FEBS Lett 2014;588:13651371.

239 Ayna G, Krysko DV, Kaczmarek A, Petrovski G, Vandenabeele P, Fésüs L: ATP release from dying autophagic cells and their phagocytosis are crucial for inflammasome activation in macrophages. PLoS One 2012; 7:e40069.

240 Kolb R, Liu GH, Janowski AM, Sutterwala FS, Zhang W: Inflammasomes in cancer: a double-edged sword. Protein Cell 2014;5:12-20.

241 McKeage MJ: Comparative adverse effect profiles of platinum drugs. Drug Safe 1995;13:228-244.

242 Kim YJ, Kim J, Tian C, Lim HJ, Kim YS, Chung JH, Choung YH: Prevention of cisplatin-induced ototoxicity by the inhibition of gap junctional intercellular communication in auditory cells. Cell Mol Life Sci doi 10.1007/ s00018-014-1594-3.

243 Qadri SM, Föller M, Lang F: Inhibition of suicidal erythrocyte death by resveratrol. Life Sci 2009;85:33-38.

244 Cheng YJ, Chang MY, Chang WW, Wang WK, Liu CF, Lin ST, Lee CH: Resveratrol enhances chemosensitivity in mouse melanoma model through connexin 43 upregulation. Environ Toxicol doi: 10.1002/tox.21952.

-245 Lee TM, Lin SZ, Chang NC: Both PKA and Epac pathways mediate N-acetylcysteine-induced Connexin43 preservation in rats with myocardial infarction. PLoS One 2013;8:e71878.

246 Moore K, Bryant ZJ, Ghatnekar G, Singh UP, Gourdie RG, Potts JD: A synthetic connexin 43 mimetic peptide augments corneal wound healing. Exp Eye Res 2013;115:178-188.

-247 Chang WW, Lai CH, Chen MC, Liu CF, Kuan YD, Lin ST, Lee CH: Salmonella enhance chemosensitivity in tumor through connexin 43 upregulation. Int J Cancer 2013;133:1926-1935.

248 Wiita AP, Hsu GW, Lu CM, Esensten JH, Wells JA: Circulating proteolytic signatures of chemotherapyinduced cell death in humans discovered by N-terminal labeling. Proc Natl Acad Sci USA 2014;111:75947599.

-249 Martyn KD, Kurata WE, Warn-Cramer BJ, Burt JM, TenBroek E, Lau AF: Immortalized connexin43 knockout cell lines display a subset of biological properties associated with the transformed phenotype. Cell Growth Differ 1997;8:1015-1027.

250 King TJ, Fukushima LH, Yasui Y, Lampe PD, Bertram JS: Inducible expression of the gap junction protein connexin43 decreases the neoplastic potential of HT-1080 human fibrosarcoma cells in vitro and in vivo. Mol Carcinog 2002;35:29-41. 
Brücher/Jamall: Cell-Cell Communication in Carcinogenesis

251 Trosko JE, Ruch RJ: Gap junctions as targets for cancer chemoprevention and chemotherapy. Curr Drug Targets 2002;3:465-482.

252 Dovzhanskiy DI, Hartwig W, Lázár NG, Schmidt A, Felix K, Straub BK, Hackert T, Krysko DV, Werner J: Growth inhibition of pancreatic cancer by experimental treatment with 4-phenylbutyrate is associated with increased expression of Connexin 43. Oncol Res 2012;20:103-111.

253 Dahl G, Keane RW: Pannexin: from discovery to bedside in 11 \pm 4 years? Brain Res 2012;1487:150-159.

254 Kondratskyi A, Yassine M, Kondratska K, Skryma R, Slomianny C, Prevarskaya N: Calcium-permeable ion channels in control of autophagy and cancer. Front Physiol 2013;4:272.

-255 Teleki I, Krenacs T, Szasz MA, Kulka J, Wichmann B, Leo C, Papassotiropoulos B, Riemenschnitter C, Moch H, Varga Z: The potential prognostic value of connexin 26 and 46 expression in neoadjuvant-treated breast cancer. BMC Cancer 2013;13:50.

256 Lee S, Margolin K: Cytokines in cancer immunotherapy. Cancers (Basel) 2011;3:3856-3893.

257 Okamoto T, Akiyama M, Takeda M, Akita N, Yoshida K, Hayashi T, Suzuki K: Connexin32 protects against vascular inflammation by modulating inflammatory cytokine expression by endothelial cells. Exp Cell Res 2011;317:348-355.

258 Ren JD, Fan L, Tian FZ, Fan KH, Yu BT, Jin WH, Tan YH, Cheng L: Involvement of a membrane potassium channel in heparan sulphate-induced activation of macrophages. Immunology 2014;141:345-352.

259 Chang-Chien J, Yen YC, Chien KH, Li SY, Hsu TC, Yang JJ: The connexin 30.3 of zebrafish homologue of human connexin 26 may play similar role in the inner ear. Hear Res 2014;313:55-66.

260 Mohit E, Rafati S: Chemokine-based immunotherapy: delivery systems and combination therapies. Immunotherapy 2012;4:807-840.

-261 Rammensee HG, Singh-Jasuja H: HLA ligandome tumor antigen discovery for personalized vaccine approach. Expert Rev Vaccines 2013;12:1211-1217.

-262 Kantoff PW, Higano CS, Shore ND, Berger ER, Small EJ, Penson DF, Redfern CH, Ferrari AC, Dreicer R, Sims RB, Xu Y, Frohlich MW, Schellhammer PF; IMPACT Study Investigators: Sipuleucel-T immunotherapy for castration-resistant prostate cancer. N Engl J Med 2010;363:411-422.

263 Huber ML, Haynes L, Parker C, Iversen P: Interdisciplinary Critique of Sipuleucel-T as Immunotherapy in Castration-Resistant Prostate Cancer. J Natl Cancer Inst 2012;104:273-279.

264 Chen G, Emens LA: Chemoimmunotherapy: reengineering tumor immunity. Cancer Immunol Immunotherapy 2013;62:203-216.

265 Hodi FS, O’Day SJ, McDermott DF, Weber RW, Sosman JA, Haanen JB, Gonzalez R, Robert C, Schadendorf D, Hassel JC, Akerley W, van den Eertwegh AJ, Lutzky J, Lorigan P, Vaubel JM, Linette GP, Hogg D, Ottensmeier CH, Lebbé C, Peschel C, Quirt I, Clark JI, Wolchok JD, Weber JS, Tian J, Yellin MJ, Nichol GM, Hoos A, Urba WJ: Improved survival with ipilimumab in patients with metastatic melanoma. N Engl J Med 2010;363:711723.

266 Devaud C, John LB, Westwood JA, Darcy PK, Kershaw MH: Immune modulation of the tumor microenvironment for enhancing cancer immunotherapy. Oncoimmunology 2013;2:e25961.

267 McAllister F, Bailey JM, Alsina J, Nirschl CJ, Sharma R, Fan H, Rattigan Y, Roeser JC, Lankapalli RH, Zhang H, Jaffee EM, Drake CG, Housseau F, Maitra A, Kolls JK, Sears CL, Pardoll DM, Leach SD: Oncogenic Kras Activates a Hematopoietic-to-Epithelial IL-17 Signaling Axis in Preinvasive Pancreatic Neoplasia. Cancer Cell 2014;25:621-637.

268 Kryczek I, Lin Y, Nagarsheth N, Peng D, Zhao L, Zhao E, Vatan L, Szeliga W, Dou Y, Owens S, Zgodzinski W, Majewski M, Wallner G, Fang J, Huang E, Zou W: IL-2+CD4+ T Cells Promote Colorectal Cancer Stemness via STAT3 Transcription Factor Activation and Induction of the Methyltransferase DOT1L. Immunity 2014;40:772-784.

269 Ferarelli LK: Unhelpful T-cells \& inflammation. Sci Signal 2014;7:ec141.

270 Ferrarelli LK: Refining the war on cancer. Sci Signal 2014;7:eg2.

271 Levin M: Endogenous bioelectrical networks store non-genetic patterning information during development and regeneration. J Physiol 2014;592:2295-2305.

272 Shi R, Borgens RB: Three-dimensional gradients of voltage during development of the nervous system as invisible coordinates for the establishment of embryonic pattern. Dev Dyn 1995;202:101-114.

-273 McCaig CD, Song B, Rajnicek AM: Electrical dimensions in cell science. J Cell Sci 2009;122:4267-4276. 